\title{
Pyrite in a sulfate-poor Paleoarchean basin was derived predominantly from elemental sulfur: Evidence from 3.2 Ga sediments in the Barberton Greenstone Belt, Kaapvaal Craton
}

\author{
Aleksandra Galić a,*, Paul R.D. Mason a , José M. Mogollón a , Mariëtte Wolthers a \\ Pieter Z. Vroon ${ }^{\mathrm{b}}$, Martin J. Whitehouse ${ }^{\mathrm{c}}$ \\ a Department of Earth Sciences, Utrecht University, Budapestlaan 4, 3584 CD Utrecht, The Netherlands \\ b Faculty of Earth and Life Sciences, VU University, De Boelelaan 1085, 1081 HV, Amsterdam, The Netherlands \\ c Department of Geosciences, Swedish Museum of Natural History, SE-10405 Stockholm, Sweden
}

\section{A R T I C L E I N F O}

Article history:

Received 19 July 2016

Received in revised form 2 December 2016

Accepted 3 December 2016

Available online 6 December 2016

\section{Keywords:}

Multiple S isotopes

Mass independent $\mathrm{S}$ fractionation

Fe isotopes

Paleoarchean pyrite

Atmospheric elemental S

Barberton Greenstone Belt

\begin{abstract}
A B S T R A C T
Multiple sulfur isotope variability in Archean sedimentary rocks provides constraints on the composition of the Earth's earliest atmosphere. The magnitude and sign of mass-independent anomalies reflect not only atmospheric processes, but also transformations due to the Archean marine sulfur cycle prior to preservation into sedimentary pyrite. The processes affecting the Archean marine sulfur cycle and the role of microbial or abiotic redox reactions during pyrite formation remain unclear. Here we combine iron $(\mathrm{Fe})$ and multiple sulfur $(\mathrm{S})$ isotope data in individual pyrite grains with petrographic information and a one-dimensional reactive transport model, to investigate the sources of Fe and $\mathrm{S}$ in pyrite formed in a Paleoarchean sedimentary basin. Pyrites were selected from mudstones, sandstones and chert obtained from a drill core in the ca. 3.2 Ga Mapepe and Mendon Formations of the Fig Tree and Onverwacht Groups, respectively, in the Barberton Greenstone Belt, Kaapvaal Craton, South Africa. Pyrite textures and $\delta^{56} \mathrm{Fe}$ distinguish early-diagenetic pyrite formed with porewater ferrous iron (disseminated grains with average $\delta^{56} \mathrm{Fe}_{\text {pyrite }}=0 \%$ ) from late-diagenetic pyrite formed through sulfidation of iron oxide minerals (layered and aggregate forms with average $\delta^{56} \mathrm{Fe}_{\text {pyrite }}=+1 \%$ ). Mass dependent $S$ isotope variability in pyrite was small $\left(\delta^{34} S_{\text {pyrite }}\right.$ ranged from -1.1 to $+3.3 \%$ ) with a correspondingly minor spread in $\Delta^{33} \mathrm{~S}_{\text {pyrite }}$ (ranging from +0.3 to $+2.1 \%$ ) and $\Delta^{36} \mathrm{~S}_{\text {pyrite }}$ (ranging from -3.08 to $+0.27 \%$ ) that indicates a lack of post-depositional re-working with other distinct sulfur sources. Our combined Fe and $\mathrm{S}$ isotope data are most readily explained with pyrite sulfide derived from microbial-reworking of solid elemental S. Iron oxide minerals were necessary to buffer sulfide concentrations and provide favorable conditions for microbial sulfur disproportionation to proceed. The lack of a negative $\Delta^{33} S$ signal indicates that pyrite from relatively deep marine diagenetic environments only partially records the products of atmospheric photolysis, consistent with low sulfate concentrations in the Paleoarchean ocean.
\end{abstract}

(c) 2016 Published by Elsevier B.V.

\section{Introduction}

Multiple sulfur isotopes $\left({ }^{32} \mathrm{~S},{ }^{33} \mathrm{~S},{ }^{34} \mathrm{~S},{ }^{36} \mathrm{~S}\right)$ preserved in Archean rocks provide information about atmospheric, biological and geological controls on the Earth's earliest sulfur cycle (Farquhar et al., 2000; Johnston, 2011). Numerical modeling and experimental work have attributed anomalous mass independent $\mathrm{S}$ isotope fractionation (MIF-S) to short-wavelength photolytic reactions involving volcanic sulfur-rich gases in a low oxygen atmosphere (Farquhar et al., 2001; Pavlov and Kasting, 2002). The most widely accepted interpretation of MIF-S is that primary atmospheric source reactions partition positive $\Delta^{33} \mathrm{~S}$

\footnotetext{
* Corresponding author.

E-mail address: a.galic@uu.nl (A. Galić).
}

(defined below in Eq. (2)) into elemental sulfur and negative $\Delta^{33} \mathrm{~S}$ into sulfate (Farquhar et al., 2000; Farquhar et al., 2014). Modelling and empirical studies show that the magnitude and sign of these atmospheric $\Delta^{33} \mathrm{~S}$ anomalies, preserved in different minerals and geological environments, was moderated by the Archean marine sulfur cycle (Halevy, 2013; Farquhar et al., 2013). Pyrite is the most abundant mineral used to track changes in Archean MIF-S. However, the role of redox chemistry, including microbial processes, in modifying atmospheric photolytic signals during incorporation of sulfur into pyrite remains unclear. Empirical studies on Archean pyrite are essential for constraining the end-products of photolysis and their preservation, but are often hampered by the complexities of the early rock record, being subject to overprinting by different sulfur sources, mixing and post-depositional re-working. 
Much of the $\Delta^{33} S$ variability in Archean sulfide minerals has been related to variable mixing of atmospheric MIF-S carried by elemental $\mathrm{S}$ and sulfate products (Ueno et al., 2008; Wacey et al., 2010; Farquhar et al., 2013; Grosch and McLoughlin, 2013; Halevy, 2013; Roerdink et al., 2013; Wacey et al., 2015). This can obscure the variability in $\Delta^{33} \mathrm{~S}$ related to the composition of atmospheric gases as well as the rate and altitude of MIF-S production (Ono et al., 2009; Halevy et al., 2010; van Zuilen et al., 2014; Claire et al., 2014; Wacey et al., 2015). The depositional environment plays an important role in modifying $S$ isotope signatures because it determines the predominant sulfur species in a specific geological setting (Halevy, 2013). For example, the magnitude of MIF-S can vary due to dilution with $\mathrm{H}_{2} \mathrm{~S}$ that carries no mass independent anomaly, since photoreactions involving volcanic (juvenile) $\mathrm{H}_{2} \mathrm{~S}$ do not generate MIF (Halevy et al., 2010), and this will be reflected in the $S$ isotopes that ultimately end up in pyrite.

The Fe isotopic composition of sedimentary pyrite can provide additional constraints on pyrite formation that may aid the interpretation of multiple S isotope variability (Archer and Vance, 2006; Marin-Carbonne et al., 2014). Fe isotopes are highly sensitive to the size and sources of the Fe and S pools from which pyrite is derived (Rouxel et al., 2005; Guilbaud et al., 2011). Iron isotopic fractionation occurs during both abiotic and biologically-mediated redox reactions (reviewed in Johnson et al., 2008). The partial oxidation of $\mathrm{Fe}^{2+}$ will yield $\mathrm{Fe}^{3+}$ with more positive $\delta^{56} \mathrm{Fe}$ between 0.9 and 3.4\% (Bullen et al., 2001; Johnson et al., 2003; Welch et al., 2003; Croal et al., 2004; Wiesli et al., 2004; Balci et al., 2006). Precipitation is also accompanied by kinetic isotope fractionation that enriches the product in the lighter isotope (Skulan et al., 2002). Bacterially mediated Fe oxide dissolution through dissimilatory iron reduction (DIR), is associated with large fractionations of up to $-3 \%$ (Crosby et al., 2007). Abiotic dissolution also initially produces relatively large fractionations, which become negligible as the reaction proceeds (Brantley et al., 2001, 2004; Wiederhold et al., 2006). Guilbaud et al. (2011) showed that abiotic processes during pyrite formation can also induce large negative $\delta^{56} \mathrm{Fe}$ fractionations of up to $-3 \%$. These values are due to kinetic effects during pyrite precipitation in a low sulfide environment. However, Wu et al. (2012) suggested that the more extreme values reported in Guilbaud et al. (2011) were unrepresentative and do not apply to typical marine systems where these values can be attenuated.

Iron isotope data for Paleoarchean pyrite is currently limited to only a few studies (Whitehouse and Fedo, 2007; Yoshiya et al., 2015a, 2015b) that find predominantly positive rather than the negative $\delta^{56} \mathrm{Fe}$ more typically associated with Neoarchean rocks (e.g. Rouxel et al., 2005). Positive $\delta^{56} \mathrm{Fe}$ has been interpreted to represent partial Fe oxidation and subsequent pyritization or remobilization of enriched Fe during metamorphism. More negative $\delta^{56} \mathrm{Fe}$ values have been suggested to reflect dissimilatory iron reduction.

In this study, we measured $\mathrm{Fe}\left({ }^{54} \mathrm{Fe},{ }^{56} \mathrm{Fe}\right)$ and multiple $\mathrm{S}$ isotopes $\left({ }^{32} \mathrm{~S},{ }^{33} \mathrm{~S},{ }^{34} \mathrm{~S},{ }^{36} \mathrm{~S}\right)$ in individual pyrite grains by secondary ionization mass spectrometry (SIMS) in order to constrain photolytic sulfur sources and the role of microbial and abiotic processes during pyrite formation. We present a unique combined Fe and multiple $\mathrm{S}$ isotope data set for samples obtained from fresh drill core that sectioned relatively deep-water sediments from an early Archean sedimentary basin. We use $\mathrm{Fe}$ and $\mathrm{S}$ isotopes to argue that $\mathrm{Fe}$ in pyrite was sourced from either porewater or reactive Fe oxides, most probably in a closed system, and that $\mathrm{S}$ was derived predominantly from atmospheric elemental $\mathrm{S}$.

\section{Geological background and sample selection}

The Barberton Greenstone Belt (BGB), Kaapvaal Craton, is a 3.6 to 3.2 Ga volcanic-sedimentary sequence divided into three main stratigraphic units. The predominantly mafic to ultramafic volcanic Onverwacht group occurs at the base, overlain by the Fig Tree group, consisting of shales, sandstones and dacitic volcaniclastic and felsic volcanic rocks, together with minor chert, banded iron formation (BIF), barite and carbonate. This is capped by the siliciclastic Moodies group, which includes quartz-rich sandstones, shales and conglomerates. The lowermost Fig Tree, and uppermost part of the Onverwacht groups, from where our samples are taken (Fig. 1), represent relatively deepwater (few $100 \mathrm{~m}$ depth) chemical and siliciclastic depositional settings, with some input from intermediate volcanism (Lowe, 1999). The BGB experienced extensive deformation and is exposed as an elongate fold-and-thrust-belt with vertically dipping or slightly overturned strata. The metamorphic grade across the center of the BGB is relatively low for Paleoarchean rocks, with maximum temperatures and pressures in the lower greenschist facies (Tice et al., 2004). However, many BGB strata experienced several phases of early diagenetic and post-burial alteration, including carbonization, sericitization, K-metasomatism and silicification (Duchac and Hanor, 1987; Rouchon and Orberger, 2008).

Our samples were obtained from the BARB4 scientific drill core, which was drilled in 2012 through approximately $550 \mathrm{~m}$ of clastic sedimentary rocks, chemical sediments, chert and ultramafic volcanic rocks of the Fig Tree and Onverwacht Groups from the Manzimnyama syncline in the East-Central Domain of the BGB. The BARB4 core intersects rocks close to the base of the 3.26-3.23 Ga Mapepe Formation of the Fig Tree Group (Lowe and Nocita, 1999) as well as the uppermost part of the underlying 3.33-3.26 Ga Mendon Formation of the Onverwacht Group (Trower and Lowe, 2016) (Fig. 1). The Mapepe section represents a quiet-water environment, below storm wave base, with abundant hematite-chert lithologies that are referred to as the Manzimnyama banded iron formation. The Manzimnyama BIF, also termed jasper or jaspilite, is an important stratigraphic marker in this part of the BGB. However, lateral correlation with other BIF-free rocks from the Lower Mapepe Formation is difficult due to the high degrees of deformation and faulting. The Mendon section consists of a thick chert unit that overlies ultramafic volcanic rocks.

The pyrite sampled for this study does not occur in the BIF or ferruginous chert, but in immediately overlying or interbedded lithic sandstones and mudstones that represent turbidites or slurry-flow units, as well as the Mendon chert. Pyrite is a rare minor phase in the BARB4 core and is largely absent in the BIF apart from occasional secondary grains. We selected seven rock samples from different stratigraphic depths to representatively cover pyrite from the sandstone, shale and chert lithologies. Pyrite textures included disseminated subhedral to euhedral grains, laminations and more irregular, but typically idiomorphic aggregate forms (Fig. 2). We also sampled pyrite from a secondary carbonate and silica filled vein at $349.81 \mathrm{~m}$ depth (sample BARB4_349.81). Almost all of the sulfide found in the samples was pyrite, with the exception of samples BARB4_340.27 and BARB4_134.27 where occasional grains of Ni-sulfide and chalcopyrite were also found. The vein in sample BARB4_349.81 contained a more diverse sulfide mineralogy, discussed further below.

The upper part of the BARB4 core, down to approximately $230 \mathrm{~m}$, consists of siliciclastic rocks from the Lower Mapepe Formation. We sampled three different lithologies from this section. All the sample names correspond to the depth in the core from which they were taken. Sample BARB4_134.27 consists of euhedral pyrite in a thin coarse-grained sandstone to gravel unit, interbedded in an area dominated by mudstone. Pyrite is a rare minor phase in this sandstone and absent in the surrounding mudstone. A single $200 \mu \mathrm{m}$ sized cubic grain was measured that overgrows into the surrounding quartzitic sandstone and gravel layer. Sample BARB4_155.55 contains large euhedral grains up to $2 \mathrm{~mm}$ across, with overgrowths at the grain boundaries into the surrounding sandstone. Cavities in the pyrite are filled with secondary silica. The sample included material taken from up to several tens of $\mathrm{cm}$ apart and was thus split into three different sub-samples denoted with the suffix _1,_2 and_3. Sample BARB4_208.85 consists of small disseminated euhedral to subhedral pyrite grains (ca. $5 \mu \mathrm{m}$, see Fig. 2) and aggregates of euhedral pyrite between 5 and 100 $\mu \mathrm{m}$ across, in a sandy mudstone matrix. 

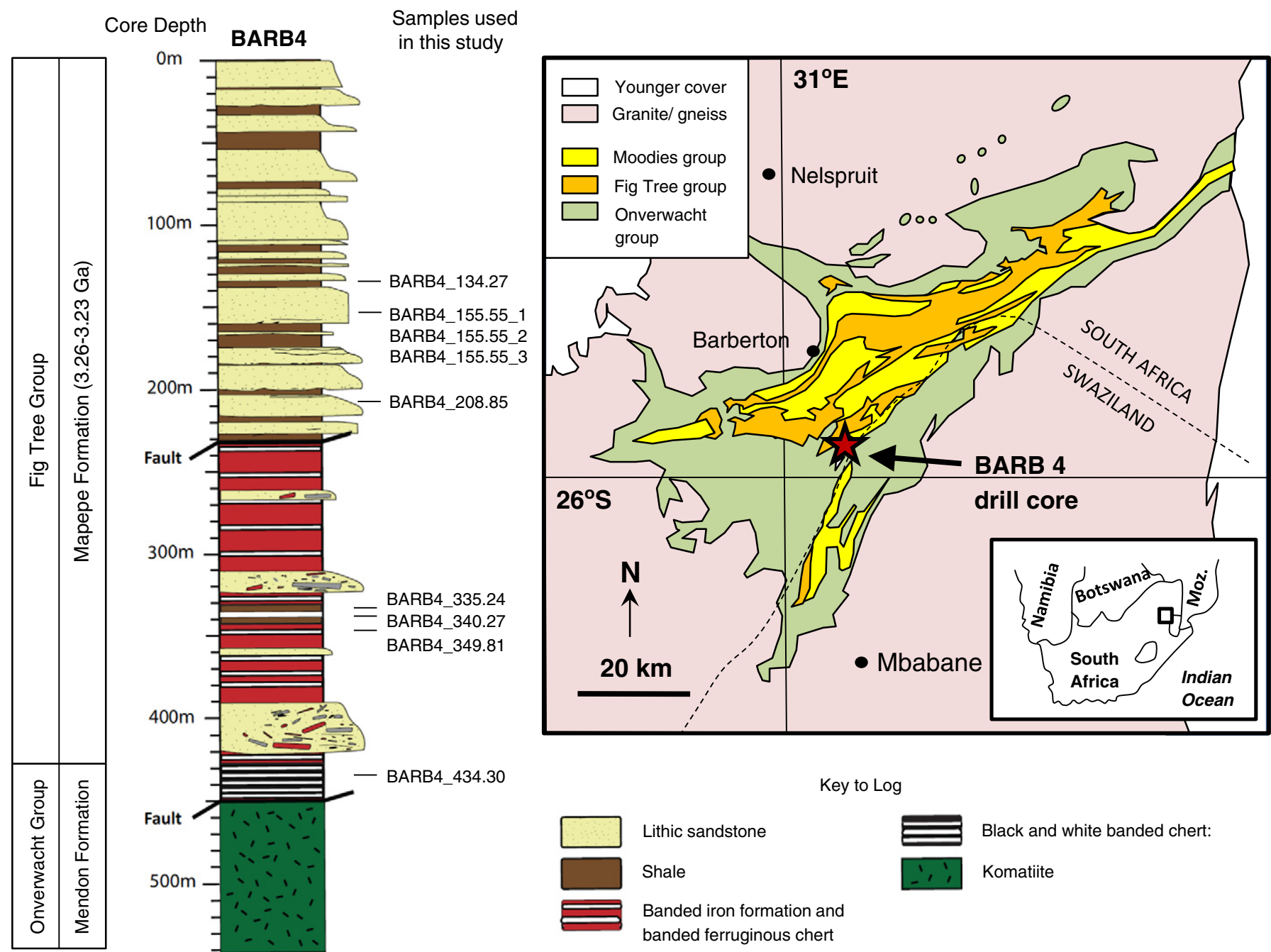

Key to Log

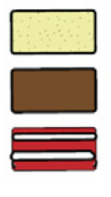

Lithic sandstone

Shale

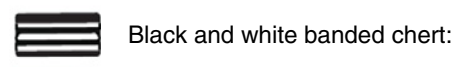

Komatiite

Banded iron formation and

banded ferruginous chert

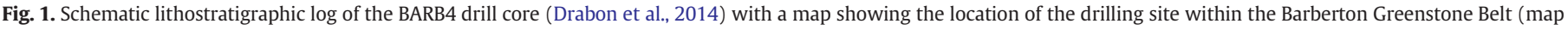
reproduced after Roerdink et al., 2013).

Three samples were taken from siliciclastic rocks interbedded with the BIF and ferruginous chert. These units most likely represent an intermittent change in depositional environment due to sediment influx or a change in water depth. Sample BARB4_335.24 consists of irregular, finely-disseminated and clumps of euhedral pyrite of between 5 and $80 \mu \mathrm{m}$ across in mudstone. Sample BARB4_340.27 occurs as laminated monomineralic pyrite and some isolated disseminated pyrite grains from beneath the lamination, interbedded in mudstone. Sample BARB4_349.81 occurs as late-stage aggregates to euhedral grains intergrown with chert, in a vein filled with ankerite and siderite.
BARB4_208.85

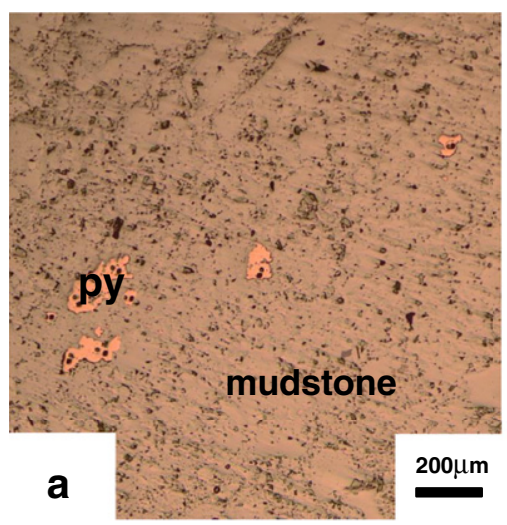

BARB4_340.27

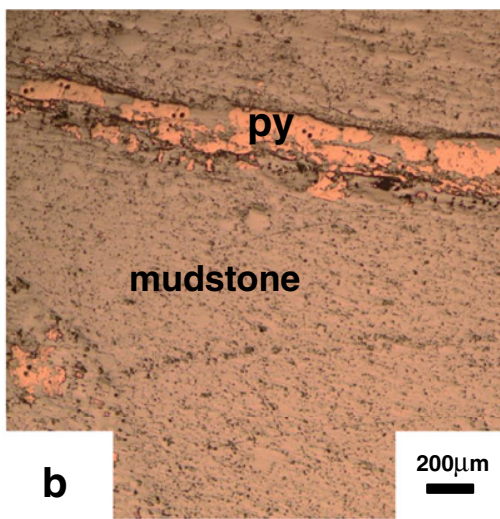

BARB4_155.55_2

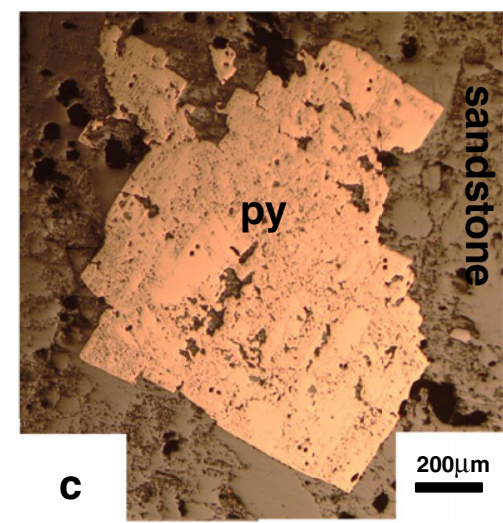

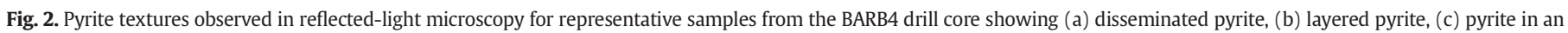
aggregate. The scale bar in each panel is $200 \mu \mathrm{m}$. 
Other sulfides were also observed in the vein including chalcopyrite and galena. Two samples were taken from different parts of the vein, several $\mathrm{cm}$ apart, in order to assess the isotopic variability associated with this secondary stage of pyrite formation.

The lowermost sample, BARB4_434.30, from the Mendon chert, occurs as more massive laminations, up to $1 \mathrm{~mm}$ across in chert. The laminations have irregular boundaries and cavities within the pyrite, which are filled with chert.

\section{Methods}

\subsection{Sample preparation and characterization}

Sulfide-rich parts of the samples were cut from the core using a diamond saw and ca. $5 \mathrm{~cm}$ diameter chips were mounted in $25 \mathrm{~mm}$ diameter epoxy resin blocks. All minerals present were characterized by transmitted and reflected light microscopy. Major and minor element concentrations were determined using a JEOL JXA 8530F field emission gun electron microprobe microanalyzer at Utrecht University. Element mapping was carried out on selected pyrite samples using both energy dispersive and wavelength dispersive spectrometers.

\subsection{Secondary ionization mass spectrometry}

Iron and multiple $S$ isotopes were measured across ca. $20 \times 20 \mu \mathrm{m}$ areas on the surface of selected pyrite grains using the CAMECA IMS1280 secondary ion mass spectrometer (SIMS) at the Swedish Museum of Natural History (NORDSIM facility). Epoxy blocks were coated with $30 \mathrm{~nm}$ gold and co-mounted with sulfide calibration and secondary standards. Analytical procedures for Fe isotope measurements were similar to those described by Whitehouse and Fedo (2007) using an $\mathrm{O}_{2}$ primary beam with an incident energy of $23 \mathrm{kV}$ and $10 \mathrm{nA}$ intensity. Multiple $S$ isotopes were measured in a separate measurement session on adjacent parts of the sample surface using a $10 \mathrm{kV}$ and $2 \mathrm{nA} \mathrm{Cs}^{+}$primary beam following the methodology reported by Kamber and Whitehouse (2007) and Whitehouse (2012) and then further developed in Roerdink et al. (2013, 2016). Standards included Ruttan pyrite with $\delta^{34} \mathrm{~S}=1.41 \pm 0.13 \%$, Balmat pyrite with $\delta^{34} \mathrm{~S}=16.22 \pm 0.35 \%$ 。 (Cabral et al., 2013) together with an anomalously fractionated pyrite from the Isua Greenstone Belt (GGU 248474) with $\delta^{34} \mathrm{~S}=1.99 \pm$ $0.36 \%$ and $\Delta^{33} \mathrm{~S}=3.31 \pm 0.19 \%$ obtained by conventional sulfur isotopic analysis (Baublys et al., 2004) (Supplementary Table S1c, S1d, S1e). Isua pyrite with $\Delta^{36} \mathrm{~S}=-2.20 \pm 0.21 \%$ (Whitehouse, 2012) was also used to monitor ${ }^{36} \mathrm{~S}$, the other standards all having $\Delta^{36} \mathrm{~S}=0 \%$ (Whitehouse, 2012) (Supplementary Table S1e). External reproducibility for Ruttan pyrite $(2 \sigma ; n=148)$ was $0.26 \%$ 。 for $\delta^{34} S, 0.17 \%$ o for $\Delta^{33} S$ and $0.66 \%$ for $\Delta^{36}$ S. During our measurement sessions the Isua monitor yielded averages, with $2 \sigma$ errors, of $\delta^{34} S=2.49 \pm 0.26 \%, \Delta^{33} \mathrm{~S}=$ $3.24 \pm 0.17 \%$ ond $\Delta^{36} \mathrm{~S}=-1.86 \pm 0.6 \%$ 。 $(n=26)$.

The uncertainty for ${ }^{56} \mathrm{Fe}$ was typically better than $0.1 \%$ 。 $(2 \sigma)$. The Balmat pyrite, with a $\delta^{56} \mathrm{Fe}$ value of -0.4 (Whitehouse and Fedo,

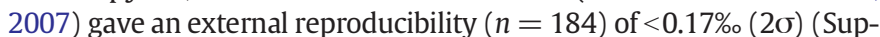
plementary Table S1f). The Fe and multiple S isotope data presented have been filtered to eliminate results with yields of $<75 \%$ of the average count rate on the standard during a given analytical session (Virtasalo et al., 2015; Roerdink et al., 2016). Sample images with measurement sites are shown in the Supplementary material together with images of trays and rock pieces from which samples were taken (Supplementary material S1 and S2).

\subsection{2 Data reporting and notation}

We report Fe and multiple $\mathrm{S}$ isotope data using standard delta notation $\left(\delta^{56} \mathrm{Fe}, \delta^{34} \mathrm{~S}, \delta^{33} \mathrm{~S}, \delta^{36} \mathrm{~S}\right)$ relative to international standards IRMM-14 and V-CDT, respectively, and expressed as:

$\delta^{\mathrm{a}} \mathrm{X}_{\text {sample }}=\left[\left({ }^{\mathrm{a}} \mathrm{X} /{ }^{\mathrm{b}} \mathrm{X}_{\text {sample }}\right) /\left({ }^{\mathrm{a}} \mathrm{X} /{ }^{\mathrm{b}} \mathrm{X}_{\text {standard }}\right)-1\right] \times 1000$

where $X$ represents Fe or S, $a$ and $b$ the heavier and lighter isotopes respectively selected from ${ }^{56} \mathrm{Fe}$ and ${ }^{54} \mathrm{Fe}$ or ${ }^{33} \mathrm{~S},{ }^{34} \mathrm{~S}$ or ${ }^{36} \mathrm{~S}$ and ${ }^{32} \mathrm{~S}$. Massindependent fractionation was calculated relative to the terrestrial fractionation line using standard methodology (Farquhar et al., 2000):

$\Delta^{33} S(\%)=\delta^{33} S-1000 \times\left[\left(1+\delta^{34} S / 1000\right)^{0.515}-1\right]$

$\Delta^{36} \mathrm{~S}(\%)=\delta^{36} \mathrm{~S}-1000 \times\left[\left(1+\delta^{34} \mathrm{~S} / 1000\right)^{1.90}-1\right]$

\subsection{Iron isotope modeling}

A one-dimensional steady-state reaction transport model (e.g. Boudreau, 1997) was used to indicate the iron isotopic signatures of two depositional regimes leading to ultimate burial of pyrite with two different isotopic signals ( $\delta^{54} \mathrm{Fe}=0 \%$ and $\delta^{56} \mathrm{Fe}=+1 \%$ ) in an Archaean shelf environment. The model couples reactions through a discretized reaction-transport equation:

$0=\frac{\partial D_{i, j} \vartheta_{i}\left(\partial C_{i, j} / \partial z\right)}{\partial z}-\frac{\partial \omega_{i} \vartheta_{i} C_{i, j}}{\partial z}+\vartheta_{i} \sum R_{i}$

where $z$ is sediment depth, and $i, j$ represent subscripts depicting depth-and species-dependence respectively. $C$ is the species concentration (aqueous or solid species, Supplementary Table 2a); $D$ is the diffusive mixing coefficient taking tortuosity into account (Boudreau, 1997); $\vartheta$ is the volume fraction for the aqueous (i.e. the porosity $\varphi_{i}$ ) or solid $\left(1-\varphi_{i}\right)$ phases; $\omega_{i}$ is the velocity of either the aqueous or the solid phase ( $v_{i}$ or $w_{i}$, respectively); $\sum R_{i}$ is the sum of the reactions affecting the given species $j$. In Eq. (4), the zero term on the left hand represents steady state. The first term of the right hand side of Eq. (4) represents diffusion, the second term represents advection, and the final term represents the reactions affecting species $j$. Biomixing was assumed to be of minor importance and was ignored from the simulations. The reactiontransport model consists of 12 geochemical species and 7 reactions (Supplementary material S4, Table 2b). The model was coded in R (version 3.2.4) using the ReacTran (Soetaert and Meysman, 2012) and marelac (Soetaert et al., 2010) packages. Burial rates were assumed to be equivalent to modern shelf settings. The code method is presented in the Supplementary material S4 with model parameters showed in Table 2c.

\section{Results}

All results are reported in Supplementary Tables S1a and S1b. Sample-averaged $\delta^{56} \mathrm{Fe}$ values in the BARB4 pyrite from the Manzimnyama syncline lie in the range from $-1.3 \%(n=2)$ in sample BARB4_155.55_3 to + 1.1\%o $(n=6)$ in BARB4_434.30 (Fig. 3). Within single samples $\delta^{56} \mathrm{Fe}$ varies between individual pyrites across a relatively large range of typically $2 \%$. More positive $\delta^{56} \mathrm{Fe}$ values are generally associated with large euhedral crystals and more voluminous pyrite masses such as layers and aggregates. $\delta^{56} \mathrm{Fe}$ values for individual grains range from $+0.5 \%$ o to $+2.5 \%$ in BARB4_ 434.30 , $+0.3 \%$ o to $+2.4 \%$ o in BARB4_340.27 and $+0.1 \%$ o to $+2.0 \%$ in BARB4_155.55_1 and BARB4_155.55_2 (Supplementary Table S1b). Smaller disseminated pyrite grains tend to have $\delta^{56} \mathrm{Fe}$ closer to $0 \%$, with $\delta^{56} \mathrm{Fe}$ variability from $-0.9 \%$ o to $+0.6 \%$ o in BARB 4 -208.85, and $-0.9 \%$ o to $+0.7 \%$ o in BARB4_335.24. The most negative $\delta^{56} \mathrm{Fe}$ were measured in two disseminated pyrite grains in BARB4_155.55_3, with $\delta^{56} \mathrm{Fe}$ of $-1.2 \%$ and- 


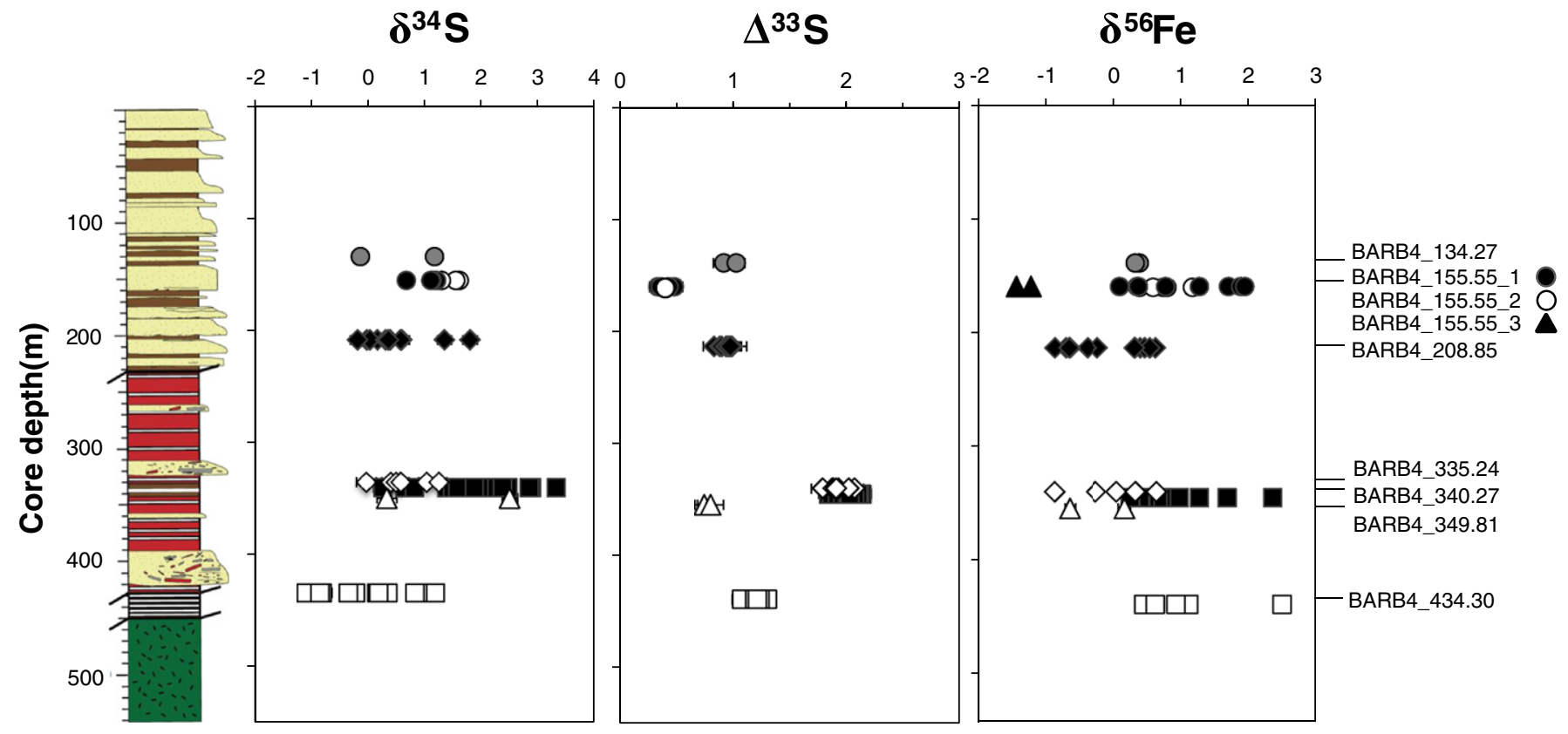

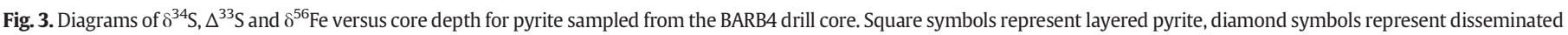

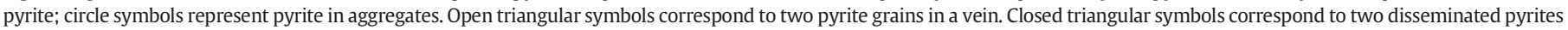
measured only for Fe isotopes. The error bars represent $1 \sigma$ error on each measured point and are frequently smaller than the symbol size.

$1.5 \%$. These latter pyrites were not measured for multiple $\mathrm{S}$ isotopes due to the small size that prevented re-measurement.

Multiple $\mathrm{S}$ isotopes were measured in the same grains as those measured for $\delta^{56} \mathrm{Fe}$, but for immediately adjacent analysis sites (Supplementary material S2). The $\delta^{34} \mathrm{~S}$ values cover a very limited range from $-1.1 \%$ o to $+3.3 \%$. $\delta^{34}$ S shows greater variability on an individual grain basis within each sample of typically up to $2 \%$, with the maximum variability of 3.1\% within sample BARB4_340.27 (Fig. 4). The smallest variability of ca. $0.5 \%$ o was observed in the pyrite aggregates in samples BARB4_155.55_1 and BARB4_155.55_2. No clear correlation was observed between pyrite textural features (disseminated, layered, euhedral, aggregate) and $\delta^{34} S$ variability. However, layered pyrite (BARB4_340.27, BARB4_434.30) together with two pyrite grains in a silica- and carbonate-rich vein in sample
BARB4_349.81 contain slightly larger $\delta^{34}$ S variability. Intra-grain variability, as observed in a single pyrite crystal in sample BARB4_134.27 reached a maximum of $2 \%$. $\Delta^{33} \mathrm{~S}$ was found to be positive and constant within analytical error for multiple pyrites within each rock sample, with similar values observed in samples from similar core depths. The minimum sample-averaged $\Delta^{33} \mathrm{~S}$ value of $0.3 \%$ $( \pm 0.2 \% \circ 1 \sigma)$ was measured for BARB4_155.55_2, with the maximum of $2.0 \%$ o $( \pm 0.2 \% \circ 1 \sigma)$ for sample BARB4_340.27 (Supplementary Table S1a). $\Delta^{36}$ S values follow an approximately $-1: 1$ relationship with $\Delta^{33} \mathrm{~S}$, with some scatter due to analytical uncertainty on $\Delta^{36} \mathrm{~S}$ for individual pyrite data (Fig. 5a). A single pyrite outlier in BARB4_340.27 is characterized by $\Delta^{36} \mathrm{~S} / \Delta^{33} \mathrm{~S}$ of -1 .7. Sample-averaged $\Delta^{33} \mathrm{~S}$ and $\Delta^{36} \mathrm{~S}$ (Fig. $5 \mathrm{~b}$ ) shows a closer fit to the Archean reference array with a $\Delta^{36} \mathrm{~S} / \Delta^{33} \mathrm{~S}$ slope of -1 .

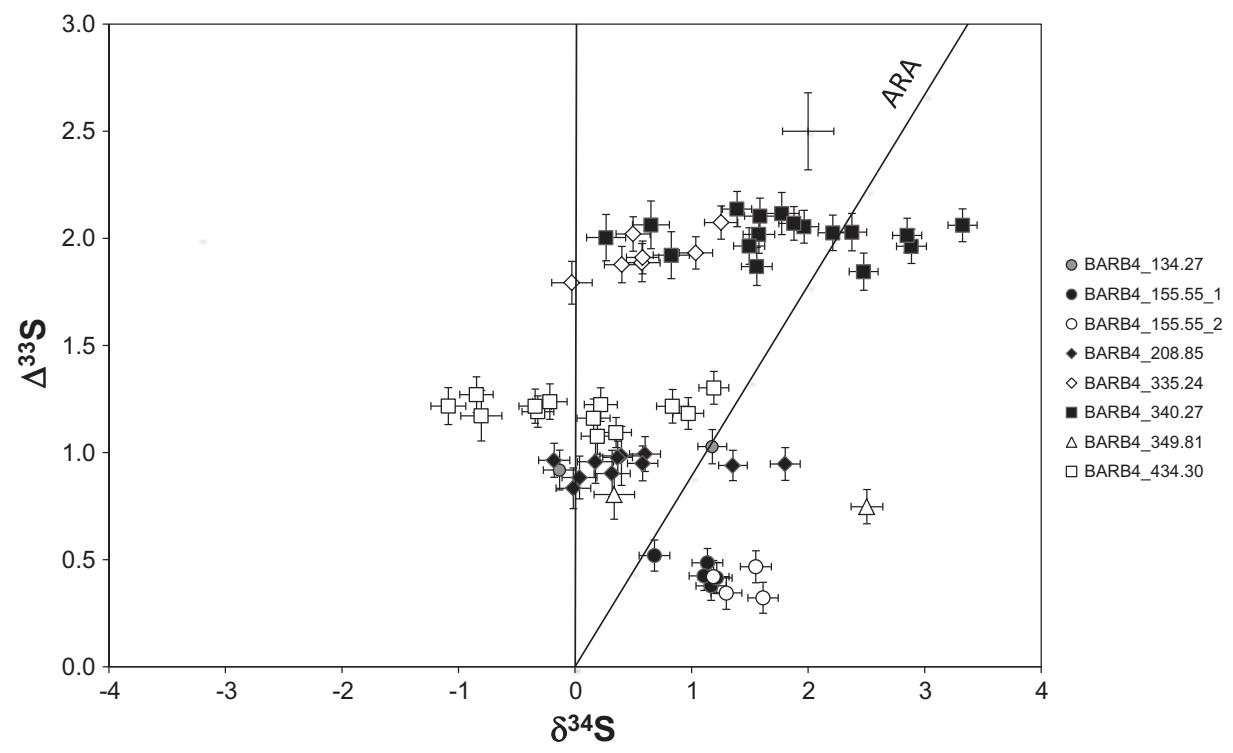

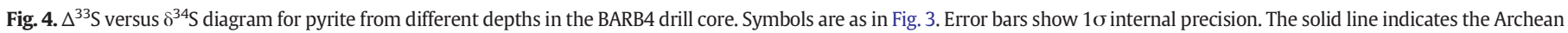

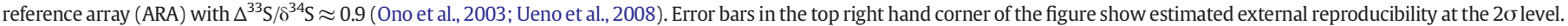




\section{a}

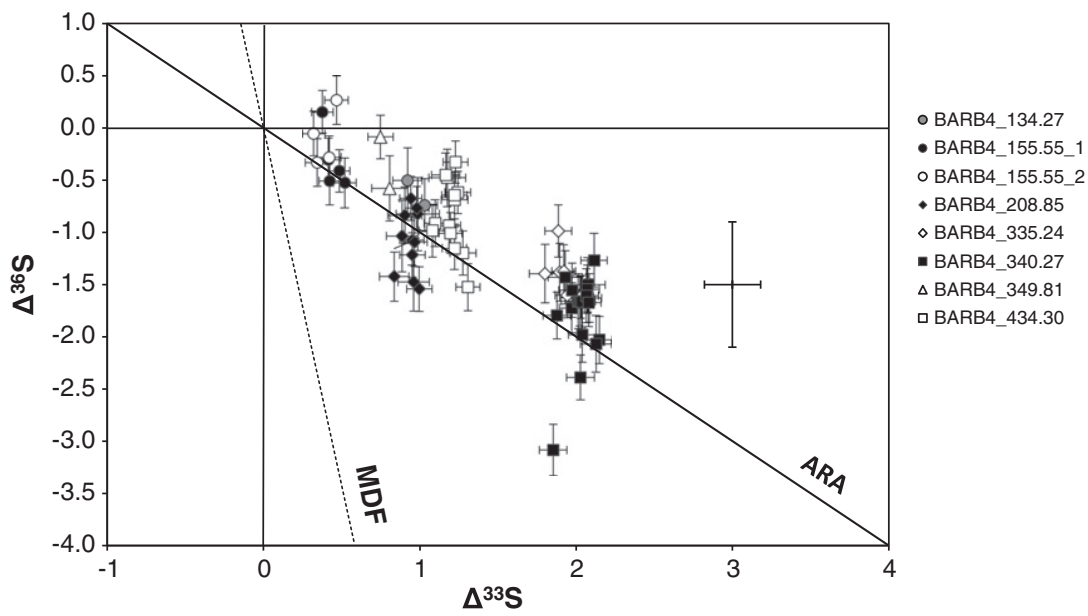

b

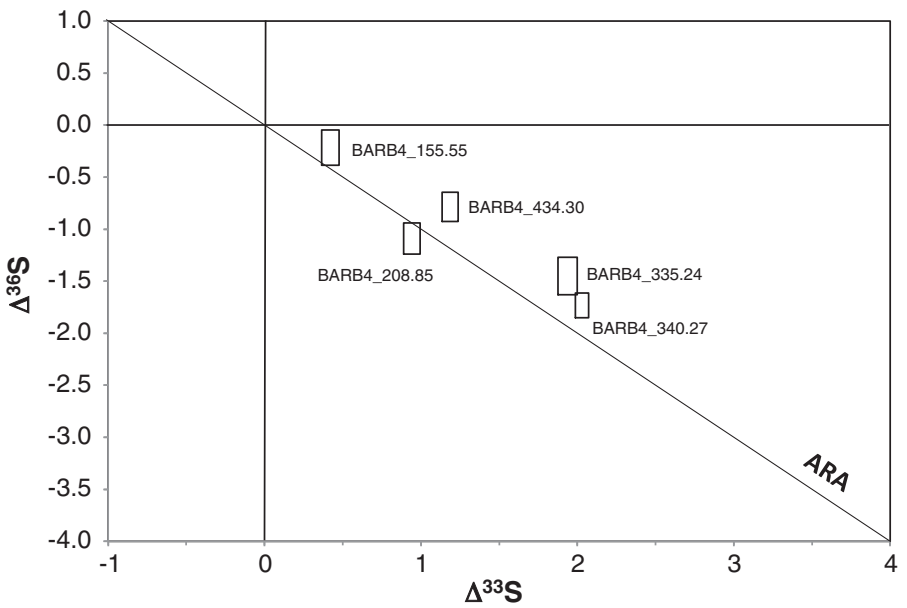

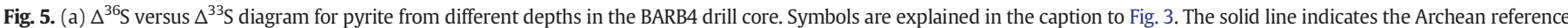

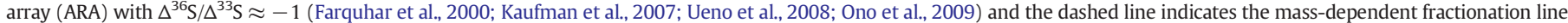

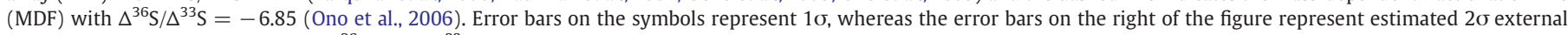

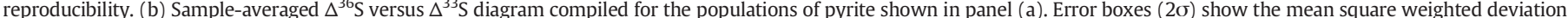

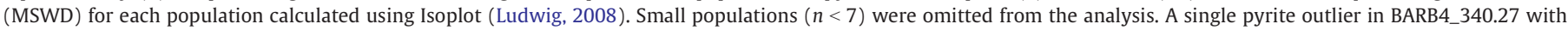
$\Delta^{36} \mathrm{~S}=-3.08$ was excluded from the MSWD calculation for this sample.

\section{Discussion}

Iron and multiple sulfur isotope data for the BARB4 drill core pyrites from the Manzimnyama syncline fall within the range identified in previous studies for sedimentary pyrite of similar Palaeoarchean age (Farquhar et al., 2000; Philippot et al., 2007; Ueno et al., 2008; Shen et al., 2009; Wacey et al., 2010; Roerdink et al., 2013, 2016; Van Zuilen et al., 2014; Wacey et al., 2015; Yoshiya et al., 2015a, 2015b). Our pyrite samples are stratigraphically similar to those measured elsewhere in the Lower Mapepe and Mendon Formations (Philippot et al., 2012; Roerdink et al., 2013), but were deposited in relatively deep water mudstones and sandstones rather than shallower water volcaniclastic sediments. Our new multiple $S$ isotope data cover a much smaller and more distinctive range than that measured for the nearby volcaniclastic sandstones (Philippot et al., 2012). Mass-independent fractionation (MIF) in our samples, recorded as $\Delta^{33} \mathrm{~S}$ or $\Delta^{36} \mathrm{~S}$, shows clear and reproducible variations with drill core depth. Constant MIF values at specific sedimentary horizons are accompanied by only minor mass-dependent fractionations $\left(\delta^{34} \mathrm{~S}\right)$. In the following discussion, we investigate how the variability in pyrite multiple $S$ isotopes can be linked to the isotopic composition of sulfur species derived from the depositional environment. We use Fe isotopes linked to an indicative reactive transport model to show how consumption of elemental sulfur, porewater Fe and sedimentary reactive Fe led to pyrite formation in an Archean ocean environment.

\subsection{Identifying primary diagenetic pyrite}

The Manzimnyama syncline pyrites cover a range of textures including disseminated, layered and aggregate forms (Fig. 2). Idiomorphic crystal faces support a diagenetic or post-diagenetic origin for the pyrite. Rounded grains of pyrite or other sulfides were not observed, indicating the lack of a detrital component. Pyrite is also absent in most of the coarser-grained sediments in the BARB4 core, beyond those studied here, where detrital iron oxides and zircon are present (Drabon et al., 2014). Turbidity currents that contributed to these coarser sediments most likely sourced material from shallower parts of the basin that were rich in Fe-oxides and were sulfide poor (Satkoski et al., 2015).

Secondary pyrite occurs at several depths in the BARB4 core as large euhedral grains that overgrow primary sedimentary structures and associated with mm-scale silica and carbonate filled veins (e.g sample BARB4_349.81). This secondary pyrite could reflect a late stage of hydrothermal sulfidization and/or reworking of precursor sulfide. The similar isotopic composition of these secondary grains with the 
remainder of the pyrite supports the latter hypothesis. A secondary stage of sulfide formation could also have produced overgrowths on inherited diagenetic or detrital cores, similar to recently reported data for nearby Moodies group sediments (Nabhan et al., 2016). To test this possibility we performed electron microprobe mapping of representative BARB4 core pyrites.

Electron microprobe maps show the pyrites to be largely homogenous in major (Fe, S) and some low-abundance trace elements $(\mathrm{Cu}$, $\mathrm{Zn}, \mathrm{Pb}, \mathrm{Se}$ ), with minor variability in $\mathrm{Ni}$, As and Co (Supplementary material S3). Pyrite cores contain irregular zones that are slightly enriched in $\mathrm{Ni}$ and depleted in $\mathrm{Co}$, with $\mathrm{Co} / \mathrm{Ni}$ typically in the range 0.5 to 5 . Cores are often porous and sometimes contain inclusions of silica or silicate minerals. A few pyrites have thin overgrowths, with enriched As and $\mathrm{Co} / \mathrm{Ni}>>1$, indicating a late stage of precipitation during diagenesis, post-depositional alteration or metamorphism (Agangi et al., 2014; Nabhan et al., 2016). Iron and multiple $S$ isotope analysis was carried out only towards the cores of relatively large grains to attain accurate and precise data, so our results were unaffected by these later stages of pyrite overgrowth.

The retention of chemical zonation in the pyrites suggests that metamorphic rehomogenization was minimal. Rehomogenization is also unlikely to have affected Fe and S isotopes since clear heterogeneity has been observed elsewhere, in pyrite $\delta^{34} \mathrm{~S}$ from nearby Moodies group sediments that underwent similar degrees of regional metamorphism (Nabhan et al., 2016). $\delta^{56} \mathrm{Fe}$ isotope variability of up to $2 \%$ in the BARB4 pyrites is as large as could be expected in the source environment or during mineral formation (Guilbaud et al., 2011), again suggesting a lack of metamorphic re-equilibration within pyrite grains. Thermochemical sulfate reduction during metamorphism is unlikely to have obscured or modified diagenetic signals due to coupled $\Delta^{36} \mathrm{~S} /$ $\Delta^{33} \mathrm{~S}$ variability (Oduro et al., 2011) observed in all our samples. We thus interpret the measured isotope ratios to be unaffected by metamorphism and to closely reflect the original variability in the diagenetic or secondary hydrothermal environment.

A lack of correlations between $\Delta^{33} S$ or $\Delta^{36} S$ and $\delta^{34} S$ within populations of pyrite, coupled with the lack of evidence for isotopic mixing lines between these populations, suggests an absence of open-system exchange between sulfur pools (Bao et al., 2008). This argues against an influence for post-depositional hydrothermal or metasomatic reworking on the pyrite cores. If reworking did occur then it took place under closed-system conditions, locally confined to individual stratigraphic layers. Secondary sulfides, including pyrite with highly variable $\mathrm{Co} / \mathrm{Ni}$, do occur in carbonate and silica veins, but are rare throughout the rest of the BARB4 drill core. The secondary pyrite has similar Fe and multiple $S$ isotope values to the remainder of the disseminated, layered and aggregated samples. This further indicates a lack of open-system behavior in the sulfur pools recorded in the pyrite and suggests that secondary reworking of sulfide was localized and would not have significantly affected primary isotopic variability. In summary, the relatively homogenous majorand trace-element distribution in the non-detrital cores of the Manzimnyama syncline pyrites is consistent with a relatively simple pyrite growth history that can be argued to resemble the Fe and multiple $\mathrm{S}$ isotopic composition of diagenetic fluids.

\subsection{Sulfur sources and atmospheric photolysis}

Mass independent fractionation of $\mathrm{S}$ isotopes in rocks older than $2.45 \mathrm{Ga}$ is thought to reflect photolytic reactions involving $\mathrm{SO}_{2}$ (or possibly SO) in a low- $\mathrm{O}_{2}$ atmosphere (Farquhar et al., 2000; Pavlov and Kasting, 2002; Ono et al., 2003; Johnston, 2011; Claire et al., 2014). The end-products of these reactions are oxidized and reduced species carrying MIF signatures of opposite sign in $\Delta^{33} S$ and $\Delta^{36} \mathrm{~S}$. In conventional models, these are interpreted to be sulfate with negative $\Delta^{33} \mathrm{~S}$, and elemental sulfur with positive $\Delta^{33} \mathrm{~S}$ (Farquhar et al., 2000; Johnston, 2011). Data from the Palaeoarchean rock record broadly support the conventional interpretation with relatively uniform and negative $\Delta^{33} \mathrm{~S}$ seen in 3.53-3.22 Ga barite deposits, thought to be derived from oceanic sulfate (Bao et al., 2007; Ueno et al., 2008; Shen et al., 2009; Roerdink et al., 2012; Halevy, 2013). Sedimentary pyrite is more heterogeneous with both negative and positive $\Delta^{33} \mathrm{~S}$, which suggests that it incorporated sulfide derived or mixed from both the oxidized and reduced photolytic pathways, with variable degrees of microbial or abiotic processing. $\delta^{34} \mathrm{~S}$ variability in Paleoarchean rocks has been linked to microbial sulfate reduction (Shen et al., 2001; Shen et al., 2009; Wacey et al., 2010; McLoughlin et al., 2012; Philippot et al., 2012; Roerdink et al., 2013; Nabhan et al., 2016), elemental S disproportionation and sulfur reduction (Philippot et al., 2007; Wacey et al., 2010) and/or abiotic processes close to hydrothermal anomalies (Grosch and McLoughlin, 2013; Roerdink et al., 2016).

Pyrite from the BARB4 core in the Manzimnyama syncline shows a variety of textural types that has a range of exclusively positive $\Delta^{33} \mathrm{~S}$ values (with correspondingly negative $\Delta^{36} S$ ). The opposite negative $\Delta^{33} \mathrm{~S}$ photolytic product is absent, with a lack of sulfate or sulfide minerals of this composition and a lack of any mixing trends in the pyrite data pointing towards this field (Figs. 4, 5a and b). Taking the conventional interpretation that Paleoarchean barite captures seawater sulfate (Farquhar et al., 2000; Bao et al., 2007; Roerdink et al., 2012; Montinaro et al., 2015), the Manzimnyama syncline pyrites would be linked to a predominantly elemental S source, with little or no mixing with sulfide derived from the sulfate reservoir. The original photolytical source could then be estimated using the Archean reference array (ARA) defined as $\Delta^{33} \mathrm{~S} / \delta^{34} \mathrm{~S}=0.9$ (Ono et al., 2003; Ueno et al., 2008) and $\Delta^{36} \mathrm{~S} / \Delta^{33} \mathrm{~S} \approx-1$ (Farquhar et al., 2000; Kaufman et al., 2007; Ueno et al., 2008; Ono et al., 2009). However, experimental work, modelling results and empirical data have been used to define photolysis arrays that differ significantly from the ARA (Farquhar et al., 2001; Lyons, 2009; Ueno et al., 2009; Masterson et al., 2011; Whitehill and Ono, 2012; Philippot et al., 2012; Whitehill et al., 2013; Claire et al., 2014). Some of these models have shown the products to be highly dependent upon the wavelength of photolysis, and can also result in sulfate with positive rather than negative $\Delta^{33} \mathrm{~S}$ values (Claire et al., 2014). Positive $\Delta^{33} \mathrm{~S}$ has been observed in much younger Neoarchean carbonate-associated sulfate (Paris et al., 2014). Low sulfate concentrations could favour a spatially and temporally heterogeneous seawater sulfate reservoir that might extend to include positive $\Delta^{33} \mathrm{~S}$ values (Muller et al., 2016). Given this, the possibility that the positive $\Delta^{33} \mathrm{~S}$ (and negative $\Delta^{36} \mathrm{~S}$ ) values were derived from sulfate rather than elemental sulfur, and with a photolysis array other than the ARA, must also be considered.

A striking aspect of the BARB4 pyrite multiple $\mathrm{S}$ isotope data is that $\Delta^{33} S$ values are constant to within analytical error at specific depths within the core, but show significant variations between samples obtained from different depths. No correlation exists between pyrite texture and $\Delta^{33} S$, (Fig. 3) suggesting that the variable $\Delta^{33} S$ was inherited from changes in the $\mathrm{S}$ source that varied with depth. Photolytic sulfate should readily homogenize following atmospheric deposition into the oceans (Farquhar et al., 2000; Roerdink et al., 2012), so that heterogeneity in the core data would require variable mixing ratios with another $\mathrm{S}$ source such as juvenile $\mathrm{S}$ or elemental $\mathrm{S}$ of opposite sign in $\Delta^{33} \mathrm{~S}$. Mixing with juvenile $S$ could readily occur during secondary pyrite reworking, but there is no evidence for this in the core, and a lack of correlation between $\mathrm{S}$ isotopic variability and pyrite textures. Variable mixing between the two photolytic products sulfate and elemental $S$ in the diagenetic component cannot be ruled out, but is unlikely since no traces of the negative $\Delta^{33} \mathrm{~S}$ component are preserved that would be required in this mixing scenario. Solid elemental $\mathrm{S}$, in contrast, could more readily retain primary atmospheric heterogeneity. Although this would be readily homogenized during diagenesis on an individual sample scale (Halevy, 2013), variable mixing between photolytic elemental sulfur and an additional component, such as sulfur produced by aqueous phase photooxidation of $\mathrm{H}_{2} \mathrm{~S}$, could account for the variability with 
depth in the core (Halevy, 2013). These arguments support conventional models where elemental $\mathrm{S}$ is the component with positive $\Delta^{33} \mathrm{~S}$.

Elemental $\mathrm{S}$ is unstable over geological timescales and can undergo a number of possible redox transformations. Incorporation of the multiple $S$ isotope signature of photolytic elemental S into pyrite requires either reduction or disproportionation reactions. All of these reactions involve only minor $\Delta^{33} \mathrm{~S}$ fractionation that would not be detectable within the external reproducibility of our SIMS data, but they can potentially be distinguished from one another due to different amounts of mass-dependent fractionation (see Johnston, 2011 for a review). Abiotic hydrolysis of elemental $S$ would produce sulfide with more positive $\delta^{34} S$ values than the reactant elemental S, with a difference of between $0.4 \%$ to 3\% (Smith, 2000). In contrast, microbial disproportionation or reduction would produce sulfide with more negative $\delta^{34} \mathrm{~S}$ (Canfield and Thamdrup, 1994; Canfield et al., 1998; Böttcher et al., 2001; Böttcher and Thamdrup, 2001; Johnston et al., 2005). The disproportionation of elemental $\mathrm{S}$ is an endergonic reaction that becomes energetically favorable when $\mathrm{H}_{2} \mathrm{~S}$ is removed from the solution by reaction with, for example, Fe or Mn (oxyhydr)oxides (Thamdrup et al., 1993; Böttcher and Thamdrup, 2001). The fractionations associated with disproportionation vary depending on the microorganisms involved, but generally give sulfate with more positive $\delta^{34} \mathrm{~S}$ by up to $18 \%$ and sulfide more negative by approximately 9\% (Canfield and Thamdrup, 1994; Habicht et al., 1998; Böttcher et al., 2001; Böttcher and Thamdrup, 2001). Isotopic fractionations associated with elemental $S$ reduction are more muted with lighter $\delta^{34} S$ values of up to $5 \%$ observed in the product sulfide (Surkov et al., 2012). Flynn et al. (2014) showed that some microorganisms combined the electron shuttling produced during enzymatic $S$ reduction to reduce Fe oxides.

We first consider a photolytic array, termed the felsic volcanic array (FVA), proposed to explain the multiple $\mathrm{S}$ isotope variability in Lower Mapepe Formation rocks of similar age to those studied here (Philippot et al., 2012). These authors propose that the $\Delta^{33} S$ versus $\delta^{34} S$ relationship was highly variable during photodissociation of sulfur dioxide, which was released into the atmosphere by short-lived intense bursts of subaerial volcanic activity (Philippot et al., 2012). Our pyrite data do not lie along the FVA as observed and modelled in the Philippot et al. (2012) study, but cover a field that could be the result of multiple injections of sulfur compounds derived from a large range of initial $\Delta^{33} \mathrm{~S}$ values, or mixing between sulfide derived from the elemental sulfur and sulfate reservoirs. Since most of the pyrite in the BARB4 core is more positive in $\delta^{34} S$ than this mixing line, it would either require an abiotic hydrolysis mechanism to produce the pyrite from elemental S (Fig. 6), or sulfur disproportionation with only the sulfate product subsequently reduced and recorded in pyrite. Several of the pyrites fall outside the range of fractionations that can be produced by these pathways. The FVA as suggested by (Philippot et al., 2012) cannot be ruled out but is unlikely to explain the Manzimnyama syncline data with an elemental S source.

The more conventional photolytic array, the Archean reference array (ARA), would have a positive slope on the $\Delta^{33} \mathrm{~S}$ versus $\delta^{34} \mathrm{~S}$ plot and passes directly through our data (Figs. 4, 5 and 6) (Ono et al., 2003; Ueno et al., 2008; Roerdink et al., 2012). Microbially mediated S disproportionation (Canfield and Thamdrup, 1994; Böttcher et al., 2001; Böttcher and Thamdrup, 2001) or microbial elemental S reduction (Surkov et al., 2012; Flynn et al., 2014) could readily result in the range of $\delta^{34} S$ observed in the pyrites of BARB4. In the case of disproportionation, the fate of the sulfate product is unclear, but it may have been partially incorporated into pyrite through an additional reduction step. If this happened to completion or at low concentration it could have muted the magnitude of the original negative offset in pyrite $\delta^{34} \mathrm{~S}$, but could also have locally produced pyrite with more positive $\delta^{34} \mathrm{~S}$ than the ARA.

The position of the positive Archean reference array, is consistent with our data. The dominant source of $\mathrm{S}$ in pyrite is most likely to have been from heterogeneous batches of elemental sulfur particles in

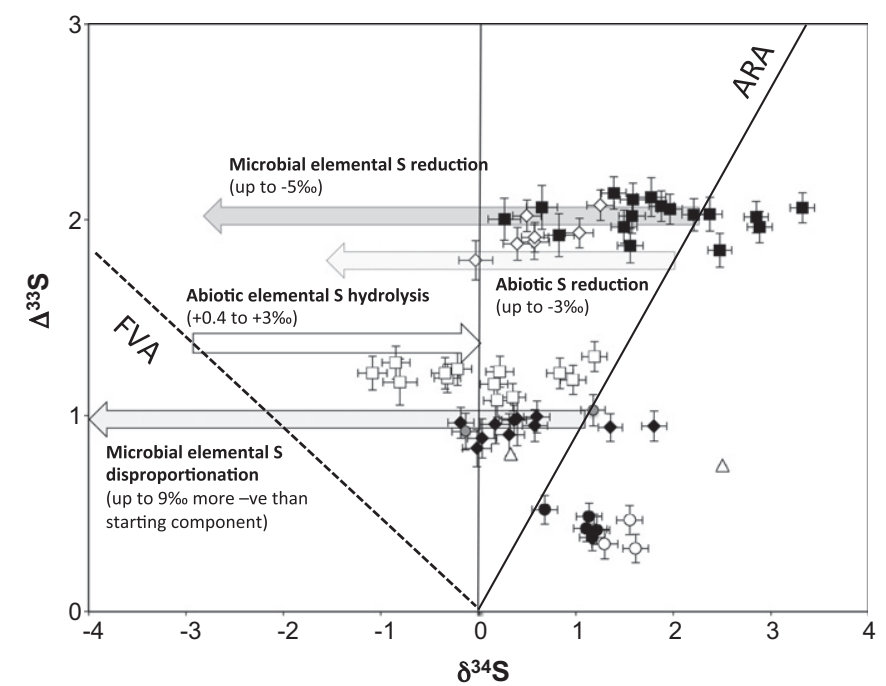

Fig. 6. $\Delta^{33} \mathrm{~S}$ versus $\delta^{34} \mathrm{~S}$ diagram showing the possible mechanisms to produce $\delta^{34} \mathrm{~S}$ variability in product sulfide that was subsequently incorporated into pyrite. Arrows indicate the amount of $\delta^{34} \mathrm{~S}$ fractionation linked to: abiotic elemental S hydrolysis (Smith, 2000), microbial elemental S reduction (Surkov et al., 2012) and microbial elemental S disproportionation (Canfield and Thamdrup, 1994; Canfield et al., 1998; Böttcher et al., 2001; Böttcher and Thamdrup, 2001; Johnston et al., 2005). The Archean reference array (ARA) is represented by a solid line and the felsic volcanic photolysis array (FVA, Philippot et al., 2012) by a dashed line. Symbols are as in Fig. 3.

the sediment, derived from sulfur aerosols that experienced photolytic MIF before settling as elemental sulfur with a positive $\Delta^{33}$ S. This idea relies on elemental $\mathrm{S}$ being the starting material that we explore further using Fe isotopes.

\subsection{Iron sources and pyrite formation}

The Archean oceans contained abundant $\mathrm{Fe}^{2+}{ }_{\text {(aq) }}$ that could be readily incorporated into pyrite following reaction with free sulfide or polysulfide. Banded iron formations in the Manzimnyama syncline, contain low- and high-Fe cherts interpreted to be shallow and deeper-water sedimentary facies (Satkoski et al., 2015). Based on these rocks, the $\delta^{56} \mathrm{Fe}$ of contemporaneous seawater has been estimated to be between $-0.5 \%$ and $0 \%$, but most likely close to $0 \%$, confirming the previous estimate of Yamaguchi et al. (2005). However, the Fe-rich minerals themselves could serve as an alternative Fe source for pyrite formation. Sedimentary reactive $\mathrm{Fe}$, would have a $\delta^{56} \mathrm{Fe}$ value of between $+0.5 \%$ 。 and $+1 \%$, based on values for hematite and magnetite in the BARB4 BIF (Satkoski et al., 2015). These Fe minerals were reworked by turbidity currents and slurry flows into the relatively Fe-poor sandstones and mudstones where pyrite is found.

Iron isotopes are not passively recorded from the water column into pyrite and can be fractionated during mineral formation by either direct abiotic mechanisms (Guilbaud et al., 2011), or indirectly through dissimilatory Fe reduction (DIR) (Crosby et al., 2007). In both cases Fe must be only partially consumed for kinetic fractionation to be observed. Pyrite formation is a multi-step process, with the initial reaction of sulfide and reactive iron to form $\mathrm{FeS}_{(\mathrm{s})}$, followed by dissolution of the solid product and reaction with aqueous polysulfide or $\mathrm{H}_{2} \mathrm{~S}$ to form pyrite (Rickard, 2012). These two latter routes are termed the polysulfide or $\mathrm{H}_{2} \mathrm{~S}$ pathways (e.g. Butler et al., 2004). The intermediate FeS phase can either be crystalline (mackinawite) or amorphous (Rickard and Luther, 2007). Abiotic dissolution is relatively slow, whereas dissimilatory iron reduction (DIR) is rapid and efficient in fractionating $\delta^{56} \mathrm{Fe}$ down to -3\% (Crosby et al., 2005). Guilbaud et al. (2011) showed experimentally that abiotic precipitation results in $\delta^{56} \mathrm{Fe}$ fractionation of $+0.5 \%$ o to $-3 \%$ in pyrite relative the source. The overlapping ranges in iron isotope fractionation preclude identification of DIR from abiological fractionation using $\delta^{56} \mathrm{Fe}$ values in the product pyrite. 

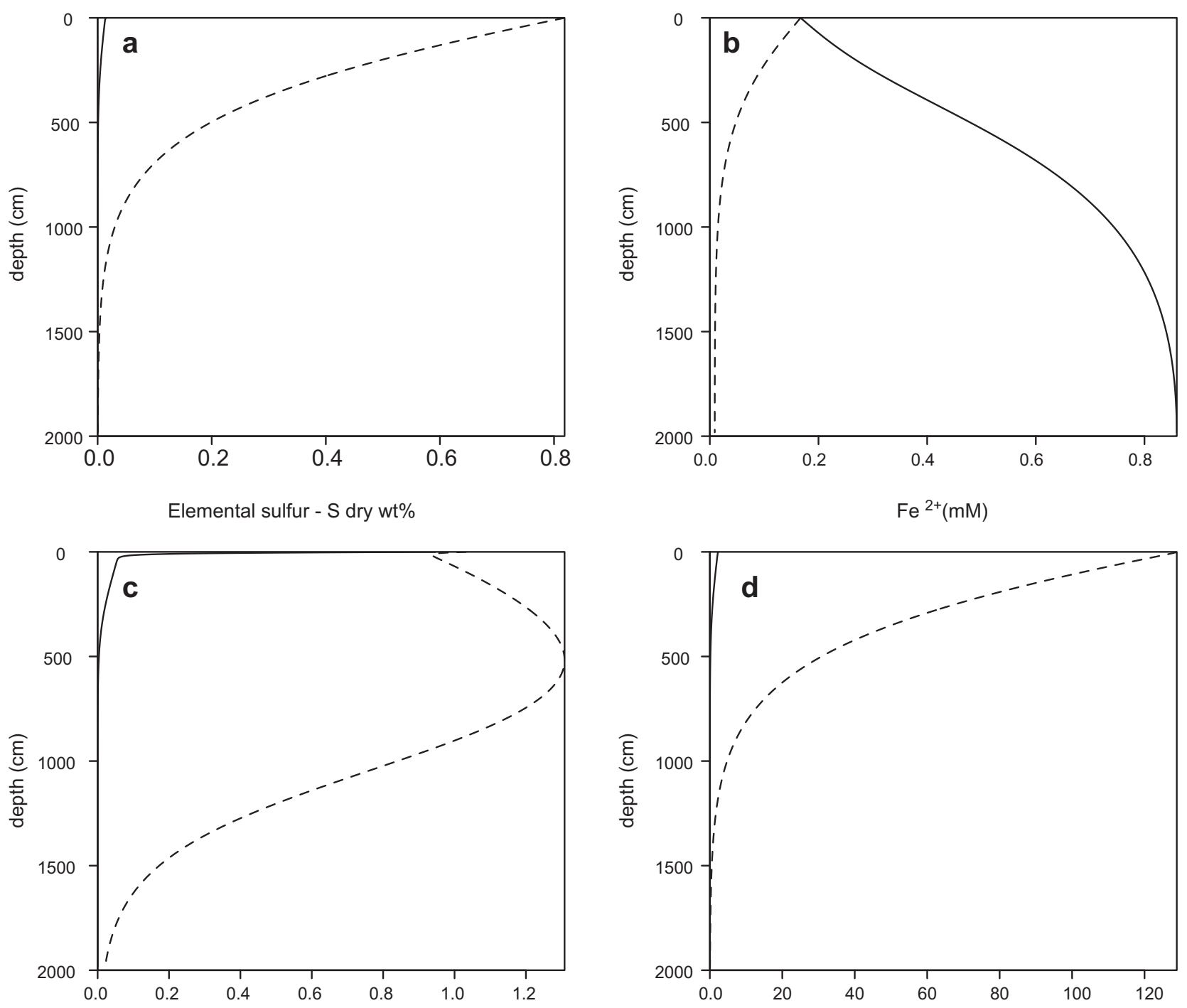

HS- $(\mu \mathrm{M})$
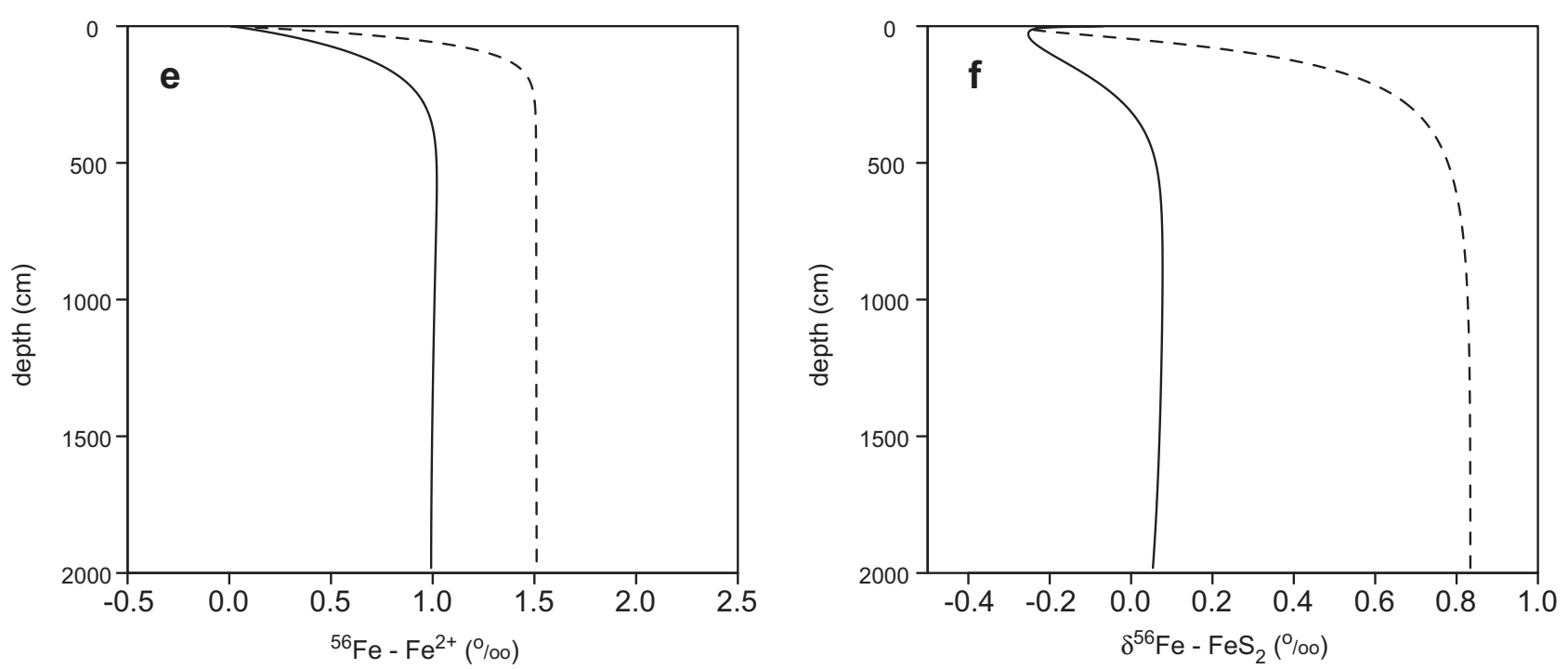

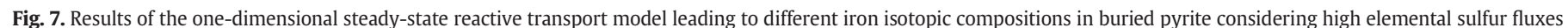

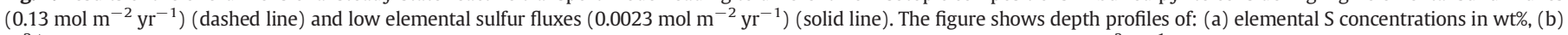

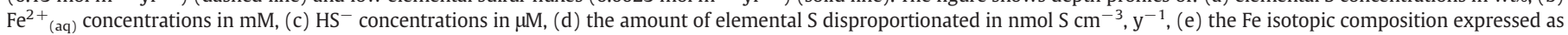
$\delta^{56} \mathrm{Fe}$ of $\mathrm{Fe}^{2+}$ in \% and (f) the Fe isotopic composition of pyrite expressed as $\delta^{56} \mathrm{Fe}$ in \%. 
Our new BARB4 pyrite data show highly variable $\delta^{56} \mathrm{Fe}$ within each sample population, that is always $>1 \%$ and frequently as large as $2 \%$, similar to other published studies (Marin-Carbonne et al., 2014; Yoshiya et al., 2015a, 2015b). The relatively large inter-grain or intralayer range in $\delta^{56} \mathrm{Fe}$ suggests either that the Fe source changed or that fractionation was induced during pyrite formation on a microscopic scale, or progressively during protracted mineral formation. The relative roles of porewater versus sedimentary reactive Fe have not been well constrained in studies of Archean pyrite formation to date. We explore these two possibilities below using an indicative one-dimensional steady state reactive-transport model that includes the propagation of the Fe isotopic signal with depth by reaction with elemental S.

The model assumes that pyrite formation occurs throughout the sediment, with the pyrite isotopic signal reflecting different $\mathrm{Fe}^{2+}$ sources. The formation of $\mathrm{Fe}^{2+}$ from the reductive dissolution of iron oxides (by hydrogen sulfide produced during the degradation of organic matter) eventually shifts the $\mathrm{Fe}^{2+}$ isotope signal toward the heavier isotopic values found in iron oxides $\left(\delta^{56} \mathrm{Fe} \approx+1 \%\right.$ o), as compared to that of the overlying water column $\left(\delta^{56} \mathrm{Fe} \approx 0 \%\right.$ ) (Fig. 7 ; complete result plots are to be found in Supplementary material 4; Figs. S4a and S4b). Organic matter fluxes were low in the Archaean in comparison to contemporary values (e.g. McCollom, 2011), and we assumed our model value to be 3 orders of magnitude lower than ranges observed in contemporary shelf environments. Dissimilatory iron reduction from organic matter degradation does not generate sufficient free iron to create a heavy iron isotopic signal in the buried pyrite. Nevertheless, the flux of elemental sulfur, considered to be the main sulfur species available in deep-water marine Archaean settings (Halevy, 2013), can provide sufficient reducing power for iron oxides via disproportionation and the generation of hydrogen sulfide. Two simulations with various elemental sulfur fluxes to the sediment reflect the ability for sediments to record light ( $\delta^{56} \mathrm{Fe} \approx 0 \%$ ) and heavy $\left(\delta^{56} \mathrm{Fe} \approx+1 \%\right.$ ) iron isotopic signals in the buried pyrite (simulation low S and high S, respectively Fig. 7). Both simulations begin with isotopically light pyrite formation due to the lighter values of $\mathrm{Fe}^{2+}$ present at the sediment surface and the fractionation associated with iron monosulfide and pyrite formation. With increasing sediment depth, however, the two simulations reveal different scenarios. Rates of sulfur disproportionation vary more than an order of magnitude within the two simulations reflecting the large difference between the two elemental sulfur fluxes. These higher rates generate more hydrogen sulfide driving the formation of both iron monosulfides and pyrite. This additional reducing power creates isotopically heavier $\mathrm{Fe}^{2+}$, which eventually becomes incorporated in iron monosulfide and pyrite. The fractionation factors chosen for the simulation are small, as larger fractionations would create more negative excursions due to the generation of lighter pyrite.

Average $\delta^{56} \mathrm{Fe}$ close to zero in disseminated pyrite measured in the BARB4 core is thus consistent with derivation from porewater $\mathrm{Fe}^{2+}$, whilst more positive $\delta^{56} \mathrm{Fe}$ in layered and aggregate pyrite suggests later-stage derivation from sedimentary reactive Fe with an elemental $\mathrm{S}$ flux equal to, or in excess of $0.13 \mathrm{~mol} \mathrm{~m}^{-2} \mathrm{yr}^{-1}$. Positive pyrite $\delta^{56} \mathrm{Fe}$ has been interpreted elsewhere to indicate sulfidization of Fe oxides (Yamaguchi et al., 2005; Whitehouse and Fedo, 2007; Hofmann et al., 2009; Nishizawa et al., 2010; Yoshiya et al., 2015a, 2015b) or alternatively to reflect the isotopic composition of a pyrite precursor that was partially oxidized (Marin-Carbonne et al., 2014). Here we suggest that an excess of sedimentary elemental $\mathrm{S}$ initially produced sulfide that consumed porewater Fe and then triggered Fe oxide dissolution during the later stages of diagenesis. Elemental S disproportionation might further be indicated by an apparent relationship between the range in $\delta^{34} S$ and the average $\delta^{56} \mathrm{Fe}$ in each pyrite population. More positive $\delta^{56} \mathrm{Fe}$ suggests the involvement of reactive, oxidized Fe in the sediment, and this Fe oxide would sustain the disproportionation reaction leading to increased $\delta^{34} S$ (Böttcher et al., 2001). More accurate knowledge of the isotopic composition of photolytic sulfur species with respect to the ARA could help to resolve this issue, and would further aid identification of the exact abiotic or metabolic pathways that produced sulfide in $\mathrm{Ar}$ chean environments.

\section{Conclusions}

Iron and multiple sulfur isotope data in pyrite from the $3.26-3.23 \mathrm{Ga}$ Fig Tree and Onverwacht Groups, South Africa, support microbial recycling of elemental sulfur as the predominant mechanism to lead to pyrite formation in Paleoarchean seafloor sediments. The conventional model of MIF-S is most consistent with our data, with a close fit to the widely proposed Archean reference array with $\Delta^{33} \mathrm{~S} / \delta^{34} \mathrm{~S}=0.9$ and $\Delta^{36} \mathrm{~S} / \Delta^{33} \mathrm{~S} \approx-1$. We used a simple one-dimensional diagenetic reactive transport model to show that $\delta^{56} \mathrm{Fe}$ in pyrite was consistent with microbial processing of elemental $\mathrm{S}$ in seafloor sediments in the presence of porewater Fe and sedimentary reactive Fe. Pyrite inherited more positive $\delta^{56} \mathrm{Fe}$ when elemental sulfur overwhelmed reactive iron in the sediment. Multiple $\mathrm{S}$ isotopes reveal that the $\mathrm{S}$ source in a marine basin setting was predominantly atmospherically-derived elemental S, with little or no input from marine sulfate.

Supplementary data to this article can be found online at http://dx. doi.org/10.1016/j.chemgeo.2016.12.006.

\section{Acknowledgements}

We thank Alice Montinaro and Harald Strauss for providing samples. The Barberton Greenstone Belt International Drilling Project and University of Johannesburg together with Nic Beukes are acknowledged for the curation of the drill core samples and Leonard Bik, Kerstin Linden, Lev Ilyinsky, Tilly Bouten and Sergei Matveev are thanked for the lab support. We thank Peter Kraal for insightful discussions on sulfur and iron cycling in modern versus Paleoarchean anoxic basins. We thank Aubrey Zerkle and one anonymous reviewer for comments that helped us to improve the manuscript. M.W. acknowledges Fellowship No. 14CSTT06 of the Foundation for Fundamental Research on Matter (FOM), which is part of The Netherlands Organisation for Scientific Research (NWO). This work was supported by a grant from the EU Synthesys program awarded to A.G. for access to the Nordsim facility, the dr Schürmannfonds for fieldwork in South Africa and grant ALWGO-PL/10-09 from the User Support Programme Space Research and the Netherlands Organization for Scientific Research (NWO). The NordSIM ion microprobe facility is a joint Nordic infrastructure. This is NordSIM publication no. 483.

\section{References}

Agangi, A., Hofmann, A., Przybyłowicz, W., 2014. Trace element zoning of sulfides and quartz at Sheba and Fairview gold mines: Clues to Mesoarchean mineralisation in the Barberton Greenstone Belt, South Africa. Ore Geol. Rev. 56, 94-114.

Archer, C., Vance, D., 2006. Coupled Fe and S isotope evidence for Archean microbial $\mathrm{Fe}$ (III) and sulfate reduction. Geology 34, 153-156.

Balci, N., Bullen, T.D., Witte-Lien, K., Shanks, W.C., Motelica, M., Mandernack, K.W., 2006 Iron isotope fractionation during microbially stimulated $\mathrm{Fe}(\mathrm{II})$ oxidation and $\mathrm{Fe}(\mathrm{III})$ precipitation. Geochim. Cosmochim. Acta 70, 622-639.

Bao, H., Rumble, D., Lowe, D.R., 2007. The five stable isotope compositions of Fig Tree barites: Implications on sulfur cycle in ca. 3.2 Ga oceans. Geochim. Cosmochim. Acta 71, 4868-4879.

Bao, H., Sun, T., Kohl, I., Peng, Y., 2008. Comment on "Early Archaean microorganisms preferred elemental sulfur, not sulfate". Science 31, 1336.

Baublys, K.A., Golding, S.D., Young, E., Kamber, B.S., 2004. Simultaneous determination of $\delta^{33} \mathrm{~S}_{\mathrm{V}-\mathrm{CDT}}$ and $\delta^{34} \mathrm{~S}_{\mathrm{V}-\mathrm{CDT}}$ using masses 48,49 and 50 on a continuous flow isotope ratio mass spectrometer. Rapid Commun. Mass Spectrom. 18, 2765-2769.

Böttcher, M.E., Thamdrup, B., 2001. Anaerobic sulfide oxidation and stable isotope fractionation associated with bacterial sulfur disproportionation in the presence of $\mathrm{MnO}_{2}$. Geochim. Cosmochim. Acta 65, 1573-1581.

Böttcher, M.E., Thamdrup, B., Vennemann, T.W., 2001. Oxygen and sulfur isotope fractionation during anaerobic bacterial disproportionation of elemental sulfur. Geochim. Cosmochim. Acta 65, 1601-1609.

Boudreau, B.P., 1997. Diagenetic Models and Their Implementation. Modeling Transport and Reactions in Aquatic Sediments. Springer-Verlag, Berlin, Germany (414 pp.).

Brantley, S.L., Liermann, L., Bullen, T.D., 2001. Fractionation of Fe isotopes by soil microbes and organic acids. Geology 29, 535-538. 
Brantley, S.L., Liermann, L.J., Guynn, R.L., Anbar, A., Icopini, G.A., Barling, J., 2004. Fe isotopic fractionation during mineral dissolution with and without bacteria. Geochim. Cosmochim. Acta 68, 3189-3204.

Bullen, T.D., White, A.F., Childs, C.W., Vivit, D.V., Schultz, M.S., 2001. Demonstration of significant abiotic iron isotope fractionation in nature. Geology 29, 699-702.

Butler, I.B., Böttcher, M.E., Rickard, D., Oldroyd, A., Bfttcher, M.E., Rickard, D., Oldroyd, A., 2004. Sulfur isotope partitioning during experimental formation of pyrite via the polysulfide and hydrogen sulfide pathways: implications for the interpretation of sedimentary and hydrothermal pyrite isotope records. Earth Planet. Sci. Lett. 228, 495-509.

Cabral, R.A., Jackson, M.G., Rose-Koga, E.F., Koga, K.T., Whitehouse, M.J., Antonelli, M.A., Farquhar, J., Day, J.M.D., Hauri, E.H., 2013. Anomalous sulphur isotopes in plume lavas reveal deep mantle storage of Archaean crust. Nature 496, 490-493.

Canfield, D.E., Thamdrup, B., 1994. The production of ${ }^{34} \mathrm{~S}$-depleted sulfide during bacterial disproportionation of elemental sulfur. Science 266, 1973-1975.

Canfield, D.E., Thamdrup, B., Fleischer, S., 1998. Isotope fractionation and sulfur metabolism by pure and enrichment cultures of elemental sulfur-disproportionating bacteria. Limnol. Oceanogr. 43, 253-264.

Claire, M.W., Kasting, J.F., Domagal-Goldman, S.D., Stüeken, E.E., Buick, R., Meadows, V.S 2014. Modeling the signature of sulfur mass-independent fractionation produced in the Archean atmosphere. Geochim. Cosmochim. Acta 141, 365-380.

Croal, L.R., Johnson, C.M., Beard, B.L., Newman, D.K., 2004. Iron isotope fractionation by $\mathrm{Fe}(\mathrm{II})$-oxidizing photoautotrophic bacteria. Geochim. Cosmochim. Acta 68 $1227-1242$.

Crosby, H.A., Johnson, C.M., Roden, E.E., Beard, B.L., 2005. Coupled Fe(II)-Fe(III) electron and atom exchange as a mechanism for $\mathrm{Fe}$ isotope fractionation during dissimilatory iron oxide reduction. Environ. Sci. Technol. 39, 6698-6704.

Crosby, H.A., Roden, E.E., Johnson, C.M., Beard, B.L., 2007. The mechanisms of iron isotope fractionation produced during dissimilatory $\mathrm{Fe}(\mathrm{III})$ reduction by Shewanella putrefaciens and Geobacter sulfurreducens. Geobiology 5, 169-189.

Drabon, N., Lowe, D.R., Heubeck, C., 2014. Petrography of sandstones from drill cores BARB4 and BARB5, Paleoarchean Mapepe Formation, Barberton greenstone belt, South Africa: Implications for provenance and tectonic reconstructions. Abstract V43D-4918 presented at 2014 Fall Meeting, AGU, San Francisco, Calif., 15-19 Dec.

Duchac, K.C., Hanor, J.S., 1987. Origin and timing of the metasomatic silicification of an early archean komatiite sequence, barberton mountain land, South Africa. Precambrian Res. 37, 125-146.

Farquhar, J., Bao, H., Thiemens, M., 2000. Atmospheric Influence of Earth's Earliest Sulfur Cycle. Science 289, 756-758.

Farquhar, J., Cliff, J., Zerkle, A.L., Kamyshny, A., Poulton, S.W., Claire, M., Adams, D., Harms, B., 2013. Pathways for Neoarchean pyrite formation constrained by mass-independent sulfur isotopes. Proc. Natl. Acad. Sci. U. S. A. 110, 17638-17643.

Farquhar, J., Savarino, J., Airieau, S., Thiemens, M.H., 2001. Observation of wavelengthsensitive mass-independent sulfur isotope effects during $\mathrm{SO}_{2}$ photolysis: Implications for the early atmosphere. J. Geophys. Res. Planets 106, 32829-32839.

Farquhar, J., Zerkle, A.L., Bekker, A., 2014. Geologic and Geochemical Constraints on Earth's Early Atmosphere. Treatise on Geochemistry, second ed. 6, pp. 91-138.

Flynn, T.M., O'Loughlin, E.J., Mishra, B., DiChristina, T.J., Kemner, K.M., 2014. Sulfurmediated electron shuttling during bacterial iron reduction. Science 344 1039-1042.

Grosch, E.G., McLoughlin, N., 2013. Paleoarchean sulfur cycle and biogeochemical surface conditions on the early Earth, Barberton, South Africa. Earth Planet. Sci. Lett. 377-378 $142-154$.

Guilbaud, R., Butler, I.B., Ellam, R.M., 2011. Abiotic pyrite formation produces a large Fe isotope fractionation. Science 332, 1548-1551.

Habicht, K.S., Canfield, D.E., Rethmeier, J., 1998. Sulfur isotope fractionation during bacterial reduction and disproportionation of thiosulfate and sulfite. Geochim. Cosmochim. Acta 62, 2585-2595.

Halevy, I. (2013) Production, preservation, and biological processing of mass-independent sulfur isotope fractionation in the Archean surface environment. Proc. Natl. Acad. Sci. U. S. A., 110, 17644-176

Halevy, I., Johnston, D.T., Schrag, D.P., 2010. Explaining the structure of the archean massindependent sulfur isotope record. Science 329, 204-207.

Hofmann, A., Bekker, A., Rouxel, O., Rumble, D., Master, S., 2009. Multiple sulphur and iron isotope composition of detrital pyrite in Archaean sedimentary rocks: A new tool for provenance analysis. Earth Planet. Sci. Lett. 286, 436-445

Johnson, C.M., Beard, B.L., Roden, E.E., 2008. The Iron Isotope Fingerprints of Redox and Biogeochemical Cycling in Modern and Ancient Earth. Annu. Rev. Earth Planet. Sci. 36, 457-493.

Johnson, C.M., Beard, B.L., Beukes, N.J., Klein, C., O'Leary, J.M., 2003. Ancient geochemical cycling in the earth as inferred from Fe isotope studies of banded iron formations from the Transvaal Craton. Contrib. Mineral. Petrol. 144, 523-547.

Johnston, D.T., 2011. Multiple sulfur isotopes and the evolution of Earth's surface sulfur cycle. Earth Sci. Rev. 106, 161-183.

Johnston, D.T., Farquhar, J., Wing, B.A., Kaufman, A.J., Canfield, D.E., Habicht, K.S., 2005. Multiple sulfur isotope fractionations in biological systems: a case study with sulfate reducers and sulfur disproportionators. Am. J. Sci. 305, 645-660.

Kamber, B.S., Whitehouse, M.J., 2007. Micro-scale sulphur isotope evidence for sulphur cycling in the late Archean shallow ocean. Geobiology 5, 5-17.

Kaufman, A.J., Johnston, D.T., Farquhar, J., Masterson, A.L., Lyons, T.W., Bates, S., 2007. Late Archean biospheric oxygenation and atmospheric evolution. Science 317, 1900-1903.

Lowe, D.R., Nocita, B.W., 1999. Foreland basin sedimentation in the Mapepe Formation, southern-facies Fig Tree Group. Geol. Soc. Am. Spec. Pap. 329, 233-258.

Lowe, D.R., 1999. Geologic evolution of the Barberton Greenstone Belt and vicinity. Spec. Pap. Geol. Soc. Am. 329, 287-312.
Ludwig, K.R., 2008. User's Manual for Isoplot 3.70. Berkeley Geochronology Center Special Publication, p. 4

Lyons, J.R., 2009. Atmospherically-derived mass-independent sulfur isotope signatures, and incorporation into sediments. Chem. Geol. 267, 164-174.

Marin-Carbonne, J., Rollion-Bard, C., Bekker, A., Rouxel, O., Agangi, A., Cavalazzi, B., Wohlgemuth-Ueberwasser, C.C., Hofmann, A., McKeegan, K.D., 2014. Coupled Fe and $\mathrm{S}$ isotope variations in pyrite nodules from Archean shale. Earth Planet. Sci. Lett. 392, 67-79.

Masterson, A.L., Farquhar, J., Wing, B.A., 2011. Sulfur mass-independent fractionation patterns in the broadband UV photolysis of sulfur dioxide: pressure and third body effects. Earth Planet. Sci. Lett. 306 (3-4), 253-260.

McCollom, T.M., 2011. What can carbon isotopes tell us about sources of reduced carbon in rocks from the Early Earth. In: Golding, Suzanne D., Glikson, Miryam (Eds.), Earliest Life on Earth: Habitats, Environments and Methods of Detection, pp. 291-311 (Springer).

McLoughlin, N., Grosch, E.G., Kilburn, M., Wacey, D., 2012. Sulfur isotope evidence for a Paleoarchean subseafloor biosphere, Barberton, South Africa. Geology 40, 1031-1034.

Montinaro, A., Strauss, H., Mason, P.R.D., Roerdink, D., Münker, C., Schwarz-Schampera, U., Arndt, N.T., Farquhar, J., Beukes, N.J., Gutzmer, J., Peters, M., 2015. Paleoarchean sulfur cycling: multiple sulfur isotope constraints from the Barberton Greenstone Belt, South Africa. Precambrian Res. 267, 311-322.

Muller, É., Philippot, P., Rollion-Bard, C., Cartigny, P., 2016. Multiple sulfur-isotope signatures in archean sulfates and their implications for the chemistry and dynamics of the early atmosphere. Proc. Natl. Acad. Sci. U. S. A. 113, 7432-7437.

Nabhan, S., Wiedenbeck, M., Milke, R., Heubeck, C., 2016. Biogenic overgrowth on detrital pyrite in ca. 3.2 Ga old Archean paleosols. Geology 44, 763-766.

Nishizawa, M., Yamamoto, H., Ueno, Y., Tsuruoka, S., Shibuya, T., Sawaki, Y., Yamamoto, S., Kon, Y., Kitajima, K., Komiya, T., Maruyama, S., Hirata, T., 2010. Grain-scale iron isotopic distribution of pyrite from Precambrian shallow marine carbonate revealed by a femtosecond laser ablation multicollector ICP-MS technique: Possible proxy for the redox state of ancient seawater. Geochim. Cosmochim. Acta 74, 2760-2778.

Oduro, H., Harms, B., Sintim, H.O., Kaufman, A.J., Cody, G., Farquhar, J., 2011. Evidence of magnetic isotope effects during thermochemical sulfate reduction. Proceedings of the National Academy of Sciences 108, 17635-17638.

Ono, S., Eigenbrode, J.L., Pavlov, A.a., Kharecha, P., Rumble, D., Kasting, J.F., Freeman, K.H., 2003. New insights into Archean sulfur cycle from mass-independent sulfur isotope records from the Hamersley Basin, Australia. Earth Planet. Sci. Lett. 213, 15-30.

Ono, S., Kaufman, A.J., Farquhar, J., Sumner, D.Y., Beukes, N.J., 2009. Lithofacies control on multiple-sulfur isotope records and Neoarchean sulfur cycles. Precambrian Res. 169, $58-67$.

Ono, S., Wing, B., Johnston, D., Farquhar, J., Rumble, D., 2006. Mass-dependent fractionation of quadruple stable sulfur isotope system as a new tracer of sulfur biogeochemical cycles. Geochim. Cosmochim. Acta 70, 2238-2252.

Paris, G., Adkins, J.F., Sessions, A.L., Webb, S.M., Fischer, W.W., 2014. Neoarchean carbonate-associated sulfate records positive $\delta^{33} \mathrm{~S}$ anomalies. Science $346,739-741$.

Pavlov, A.A., Kasting, J.F., 2002. Mass-independent fractionation of sulfur isotopes in Archean sediments: strong evidence for an anoxic Archean atmosphere. Astrobiology 2, 27-41.

Philippot, P., van Zuilen, M., Lepot, K., Thomazo, C., Farquhar, J., Van Kranendonk, M.J., 2007. Early Archaean microorganisms preferred elemental sulfur, not sulfate. Science 317, 1534-1537.

Philippot, P., van Zuilen, M., Rollion-Bard, C., 2012. Variations in atmospheric sulphur chemistry on early Earth linked to volcanic activity. Nat. Geosci. 5, 668-674.

Rickard, D., 2012. Sulfidic Sediments and Sedimentary Rocks, Developments in sedimentology, 65. Elsevier, Amsterdam (816 pp.).

Rickard, D., Luther, G.W., 2007. Chemistry of iron sulfides. Chem. Rev. 107, 514-562.

Roerdink, D.L., Mason, P.R.D., Farquhar, J., Reimer, T., 2012. Multiple sulfur isotopes in Paleoarchean barites identify an important role for microbial sulfate reduction in the early marine environment. Earth Planet. Sci. Lett. 331-332, 177-186.

Roerdink, D.L., Mason, P.R.D., Whitehouse, M.J., Reimer, T., 2013. High-resolution quadruple sulfur isotope analyses of $3.2 \mathrm{Ga}$ pyrite from the Barberton Greenstone Belt in South Africa reveal distinct environmental controls on sulfide isotopic arrays. Geochim. Cosmochim. Acta 117, 203-215.

Roerdink, D.L., Mason, P.R.D., Whitehouse, M.J., Brouwer, F.M., 2016. Reworking of atmospheric sulfur in a Paleoarchean hydrothermal system at Londozi, Barberton Greenstone Belt, Swaziland. Precambrian Res. 280, 195-204.

Rouchon, V., Orberger, B., 2008. Origin and mechanisms of K-Si-metasomatism of ca. 3.4$3.3 \mathrm{Ga}$ volcaniclastic deposits and implications for Archean seawater evolution: Examples from cherts of Kittys Gap (Pilbara craton, Australia) and Msauli (Barberton Greenstone Belt, South Africa). Precambrian Res. 165, 169-189.

Rouxel, O.J., Bekker, A., Edwards, K.J., 2005. Iron isotope constraints on the Archean and Paleoproterozoic ocean redox state. Science 307, 1088-1091.

Satkoski, A.M., Beukes, N.J., Li, W., Beard, B.L., Johnson, C.M., 2015. A redox-stratified ocean 3.2 billion years ago. Earth Planet. Sci. Lett. 430, 43-53.

Shen, Y., Buick, R., Canfield, D.E., 2001. Isotopic evidence for microbial sulphate reduction in the early Archaean era. Nature 410, 77-81.

Shen, Y., Farquhar, J., Masterson, A., Kaufman, A.J., Buick, R., 2009. Evaluating the role of microbial sulfate reduction in the early Archean using quadruple isotope systematics. Earth Planet. Sci. Lett. 279, 383-391.

Skulan, J.L., Beard, B.L., Johnson, C.M., 2002. Kinetic and equilibrium Fe isotope fractionation between aqueous $\mathrm{Fe}$ (III) and hematite. Geochim. Cosmochim. Acta 66, 2995-3015.

Smith, J.W., 2000. Isotopic fractionations accompanying sulfur hydrolysis. Geochem. J. 34, 95-99.

Soetaert, K., Meysman, F., 2012. R-package ReacTran: Reactive Transport Modelling in R Environ. Model. Softw. 32, 49-60. 
Soetaert, K., Petzoldt, T., Setzer, R.W., 2010. Solving Differential Equations in R. R Journal 2, $5-15$.

Surkov, A.V., Böttcher, M.E., Kuever, J., 2012. Sulphur isotope fractionation during the reduction of elemental sulphur and thiosulphate by Dethiosulfovibrio spp. Isot. Environ. Health Stud. 48, 65-75.

Thamdrup, B.O., Finster, K.M., Hansen, J.W.W., Thamdrup, B.O., Finster, K.M., Hansen, J.W.W., 1993. Bacterial Disproportionation of Elemental Sulfur Coupled to Chemical Reduction of Iron or Manganese Bacterial Disproportionation of Elemental Sulfur Coupled to Chemical Reduction of Iron or Manganese. Appl. Environ. Microbiol. 59, $101-108$.

Tice, M.M., Bostick, B.C., Lowe, D.R., 2004. Thermal history of the 3.5-3.2 Ga Onverwacht and Fig Tree Groups, Barberton greenstone belt, South Africa, inferred by Raman microspectroscopy of carbonaceous material. Geology 32, 37-40.

Trower, E.J., Lowe, D.R., 2016. Sedimentology of the 3.3 Ga upper Mendon Formation, Barberton Greenstone Belt, South Africa. Precambrian Res. 281, 473-494.

Ueno, Y., Johnson, M.S., Danielache, S.O., Eskebjerg, C., Pandey, A., Naohiro Yoshida, N., 2009. Geological sulfur isotopes indicate elevated OCS in the Archean atmosphere, solving faint young sun paradox. Proc. Natl. Acad. Sci. U. S. A. 106 (35), 14784-14789.

Ueno, Y., Ono, S., Rumble, D., Maruyama, S., 2008. Quadruple sulfur isotope analysis of ca. 3.5 Ga Dresser Formation: New evidence for microbial sulfate reduction in the early Archean. Geochim. Cosmochim. Acta 72, 5675-5691.

Van Zuilen, M.A., Philippot, P., Whitehouse, M.J., Lepland, A., 2014. Sulfur isotope mass-independent fractionation in impact deposits of the 3.2 billion-year-old Mapepe Formation, Barberton Greenstone Belt, South Africa. Geochim. Cosmochim. Acta 142, 429-441.

Virtasalo, J.J., Laitala, J.J., Lahtinen, R., Whitehouse, M.J., 2015. Pyritic event beds and sulfidized Fe (oxyhydr)oxide aggregates in metalliferous black mudstones of the Paleoproterozoic Talvivaara formation, Finland. Earth Planet. Sci. Lett. 432, 449-460.

Wacey, D., McLoughlin, N., Whitehouse, M.J., Kilburn, M.R., 2010. Two coexisting sulfur metabolisms in a ca. 3400 Ma sandstone. Geology 38, 1115-1118.

Wacey, D., Noffke, N., Cliff, J., Barley, M.E., Farquhar, J., 2015. Micro-scale quadruple sulfur isotope analysis of pyrite from the $3480 \mathrm{Ma}$ Dresser Formation: New insights into sulfur cycling on the early Earth. Precambrian Res. 258, 24-35.

Welch, S.A., Beard, B.L., Johnson, C.M., Braterman, P.S., 2003. Kinetic and equilibrium Fe isotope fractionation between aqueous $\mathrm{Fe}(\mathrm{II})$ and $\mathrm{Fe}(\mathrm{III})$. Geochim. Cosmochim. Acta 67, 4231-4250.
Whitehill, A.R., Ono, S., 2012. Excitation band dependence of sulfur isotope mass-independent fractionation during photochemistry of sulfur dioxide using broadband light sources. Geochim. Cosmochim. Acta 94, 238-253.

Whitehill, A.R., Xie, C., Hu, X., Xie, D., Guo, H., Ono, S., 2013. Vibronic origin of sulfur massindependent isotope effect in photoexcitation of $\mathrm{SO}_{2}$ and the implications to the early earth's atmosphere. Proc. Natl. Acad. Sci. U. S. A. 110, 17697-17702.

Whitehouse, M.J., 2012. Multiple Sulfur Isotope Determination by SIMS: Evaluation of Reference Sulfides for $\Delta^{33} \mathrm{~S}$ with Observations and a Case Study on the Determination of $\Delta^{36}$ S. Geostand. Geoanal. Res. 37, 19-33.

Whitehouse, M.J., Fedo, C.M., 2007. Microscale heterogeneity of Fe isotopes in >3.71 Ga banded iron formation from the Isua Greenstone Belt, southwest Greenland. Geology 35, 719-722.

Wiederhold, J.G., Kraemer, S.M., Teutsch, N., Borer, P.M., Halliday, A.N., Kretzschmar, R. 2006. Iron isotope fractionation during proton-promoted, ligand-controlled, and reductive dissolution of goethite. Environ. Sci. Technol. 40, 3787-3793.

Wiesli, R.A., Beard, B.L., Johnson, C.M., 2004. Experimental determination of Fe isotope fractionation between aqueous Fe(II), siderite and "green rust" in abiotic systems. Chem. Geol. 211, 343-362.

Wu, L., Druschel, G., Findlay, A., Beard, B.L., Johnson, C.M., 2012. Experimental determination of iron isotope fractionations among $\mathrm{Fe}^{2+}{ }_{\text {aq }}-\mathrm{FeS}_{\mathrm{aq}}$-Mackinawite at low temperatures: Implications for the rock record. Geochim. Cosmochim. Acta 89, 46-61.

Yamaguchi, K.E., Johnson, C.M., Beard, B.L., Ohmoto, H., 2005. Biogeochemical cycling of iron in the Archean-Paleoproterozoic Earth: Constraints from iron isotope variations in sedimentary rocks from the Kaapvaal and Pilbara Cratons. Chem. Geol. 218 135-169.

Yoshiya, K., Nishizawa, M., Sawaki, Y., Ueno, Y., Komiya, T., Yamada, K., Yoshida, N., Hirata, T., Wada, H., Maruyama, S., 2015b. In situ iron isotope analyses of pyrite and organic carbon isotope ratios in the Fortescue Group: Metabolic variations of a Late Archean ecosystem. Precambrian Res. 212-213, 169-193.

Yoshiya, K., Sawaki, Y., Shibuya, T., Yamamoto, S., Komiya, T., Hirata, T., Maruyama, S. 2015a. In-situ iron isotope analyses of pyrites from 3.5 to $3.2 \mathrm{Ga}$ sedimentary rocks of the Barberton Greenstone Belt, Kaapvaal Craton. Chem. Geol. 403, 58-73. 